\title{
Progetto e memoria. Connessioni e trame grafiche per il Museo di Scienze Naturali di La Plata
}

\author{
Fabiana Carbonari \\ Emanuela Chiavoni \\ Giulia Pettoello \\ Francesca Porfiri \\ María Belén Trivi
}

Abstract

Sin dalla sua creazione, nel 1905, l'Università Nazionale di La Plata - UNLP - è stata oggetto di molteplici studi sulla sua storia, le sue linee tematiche, i suoi laureati illustri e sulla sua architettura. Le connessioni tra pensiero visivo, politiche accademiche e campo disciplinare che sostengono le relative produzioni artistiche sono significative, soprattutto considerando le diverse influenze e la formazione dei suoi autori. In questo contesto, il lavoro propone di riflettere e diffondere il ricco patrimonio culturale e scientifico del Museo di Scienze Naturali per consolidarne la memoria. Al fine della sua conoscenza sono stati analizzati alcuni disegni, realizzati con modalità diverse, nella loro evoluzione storica. Questi elaborati grafici mostrano i legami tra i modi di vedere e rappresentare l'edificio e il suo ricco patrimonio museale. I disegni del progetto originario raccontano l'edificio accademico di linguaggio eclettico creato da K. Heynemann e H. Äberg ma lo studio proposto vuole focalizzare l'attenzione sulle espressioni degli anni '90, che corrispondono ai moderni interventi dei primi laureati della Facoltà di Architettura e Urbanistica - FAU-UNLP- come Vicente Krause; un architetto che ha saputo cogliere con le sue sperimentazioni grafiche l'identità dell'edificio in oggetto, proponendone un ampliamento organico possibile, purtroppo mai realizzato.

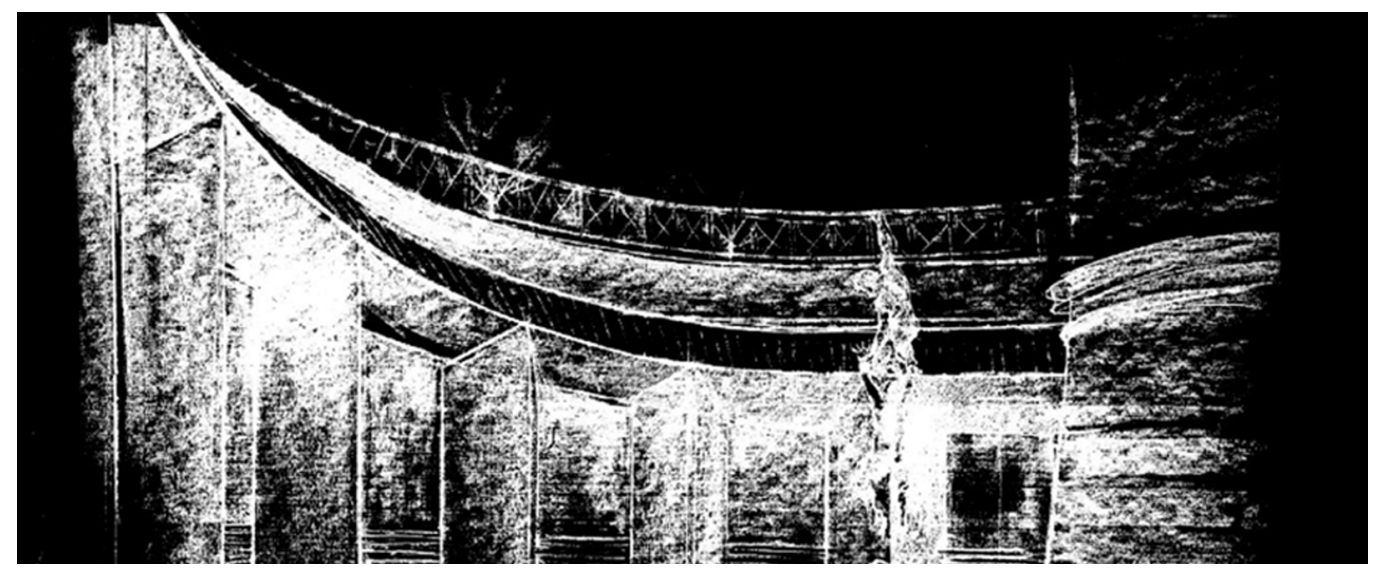




\section{Introduzione}

II contributo affronta la tematica della connessione, intesa come volontà di 'ricostruire' la memoria di un importante edificio, situato nella città di La Plata, attorno al quale si intrecciano - come trame di un tessuto - narrazioni progettuali legate a diverse epoche, tra cui risulta interessante un particolare progetto di ampliamento mai realizzato, ma raccontato attraverso diversi elaborati grafici. A partire da essi è stata condotta una lettura critica disegnata che, unita ad un'analisi storico-documentaristica ha portato alla ricostruzione dell'identità del progetto, immaginandone la sua realizzazione [ I ]. Si tratta di una modalità di comunicazione declinata secondo diversi aspetti - storico, urbanistico, artistico, materico, geometrico, emozionale - con lo stesso scopo, quello di 'ricucire' tutti gli elementi a disposizione. II fine ultimo è consolidare la memoria di un patrimonio immateriale, culturale e scientifico, mettendo a sistema una serie di dati di achivio di cui fanno parte anche i progetti mai realizzati [2].

\section{Origine del Museo}

Nell'anno 1877 fu creato il Museo Antropologico e Archeologico di Buenos Aires per ospitare le collezioni donate da Francisco Pascacio Moreno, nominato poi direttore a vita. Dopo la federalizzazione di Buenos Aires e la creazione della città di La Plata il museo si trasferì nella nuova capitale provinciale con il nome di Museo delle Scienze Naturali di La Plata, il primo edificio concepito come un museo della Repubblica Argentina.

II progetto di costruzione dalla sua sede fu realizzato nel 1884 dall'architetto svedese Henrik Äberg, affiancato dal giovane architetto tedesco Karl Heynemann. Tale architettura ha consentito di esporre i 15000 pezzi che erano nel Museo Antropologico e Archeologico di Buenos Aires. Nel 1906, l'edificio del nuovo Museo completo delle collezioni fu ceduto dal governo provinciale all'Università Nazionale di La Plata, di recente creazione. Tutte le attività accademiche e di ricerca sono state incorporate quando la Facoltà di Scienze Naturali e Antropologiche, e quella di Chimica e Farmacia hanno iniziato a lavorare insieme.

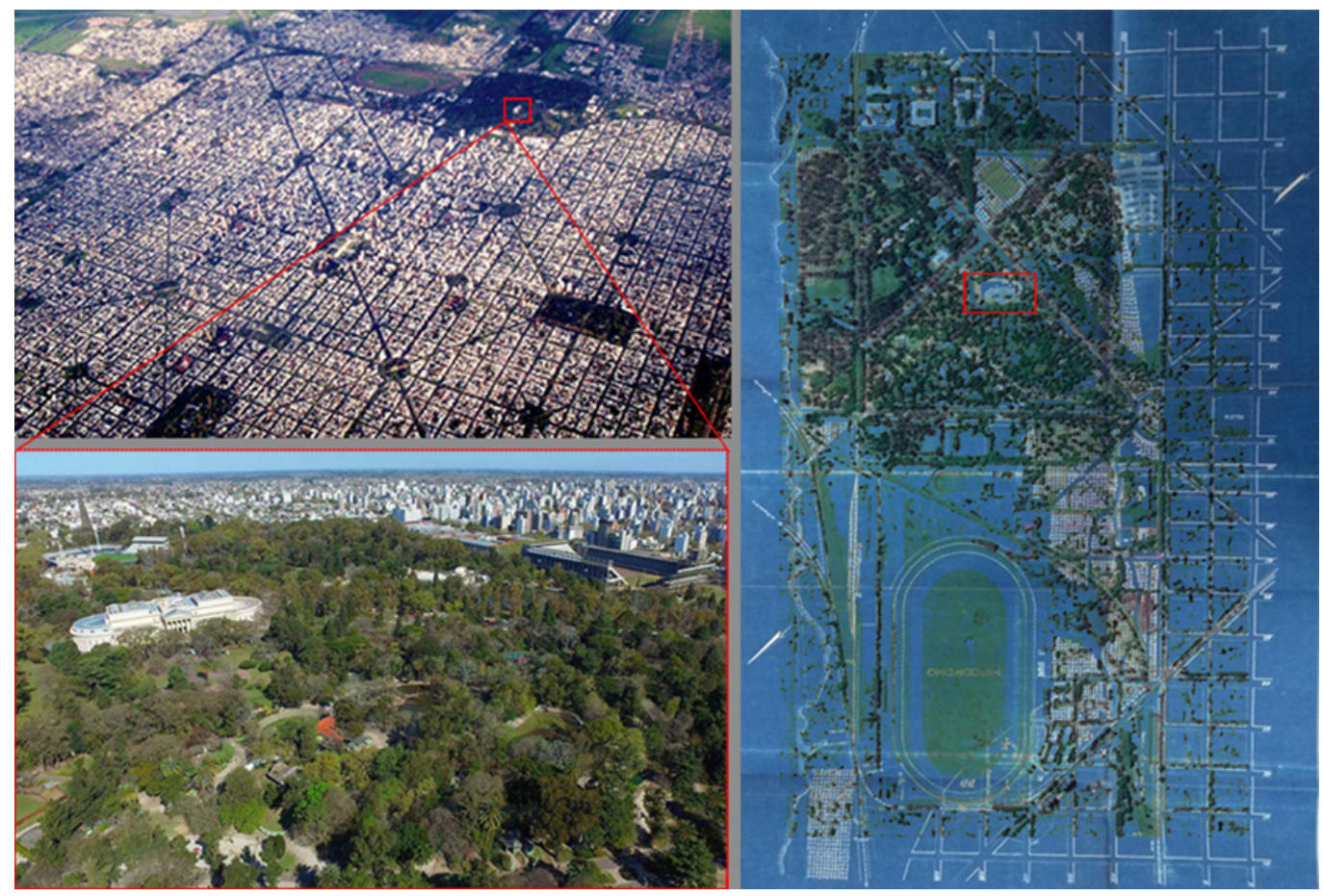


La localizzazione del museo, nello spazio bucolico del 'Bosche', è determinata dalla visione integrale di González, creatore della Universidad Nacional de La Plata, che tendeva a collegare l'arte e la cultura nello stesso settore urbano, tra il regno animale e vegetale attraverso il Museo, lo Zoo, la Foresta e l'Osservatorio astronomico (fig. I).

L'edificio, realizzato secondo i postulati accademici, presenta un percorso ad anello e due semicerchi alle estremità del volume di base. Lo stile neoclassico adottato da Aberg riflette gli ideali che la società nascente doveva raggiungere, ed alcuni tratti dell'accademismo tedesco. Lo spazio si sviluppa su tre livelli inclusi uno interrato e il piano nobile (fig. 2).

Il carattere monumentale del portico con sei colonne di ordine corinzio, alla maniera di Schinkel, caratterizza l'opera, la sua volumetria orizzontale contrasta, in modo romantico, con l'ambiente circostante.

II lavoro riflette diverse influenze che includono: il British Museum e la National Gallery di Londra, la New Gallery of the Evolution di Parigi, l'Alte Pinakothek e il Glyptotek di Munich, l'Altes Museum di Berlino, il Fitzwilliam Museum di Cambridge e la Smithsonian Institution di Washington. L'idea generale consiste in un chiaro anello perimetrale che consente di esplorare, al piano inferiore e al primo livello, le diverse mostre [3]. I diversi volumi rispondono alle funzioni in modo simmetrico, c'è una gradazione di tensioni dal punto maggiormente significativo, attribuito al volume dominante dell'ingresso con la sala di pianta circolare centrale. La facciata ha un basamento cieco con ritmo generato da lesene e pannelli nella parte centrale e aperture nei settori laterali, la finitura superiore è costituita da una balaustra continua. II portico principale di accesso corinzio, situato sull'asse centrale dell'edificio, contrasta con i due portici ionici più piccoli che sono sormontati da volumi che contengono spazi espositivi differenziati. L'ornamento è scarso e i motivi americani precolombiani utilizzati appaiono per la prima volta in un edificio pubblico argentino. I gruppi scultorei furono realizzati dallo scultore italiano Víctor de Pol (fig. 3).

Non di minor pregio è lo spazio interno: in maniera simile a quella dei grandi palazzi del XIX secolo, vengono rivelate risoluzioni costruttive basate sull'uso di nuovi materiali come ferro e vetro, e la creazione di ambienti particolari per ogni tipo di mostra. Lo studio dettagliato delle luci e delle forme genera un effetto scenico in cui il contrasto tra l'illuminazione e i pezzi esposti assume un ruolo fondamentale. II percorso attraverso quegli spazi pieni di espressività é chiaro e ordinato. Le qualità spaziali sono raggiunte attraverso la progettazione di aperture, sorgenti luminose, variazioni dimensionali e qualità dei materiali (fig. 4).

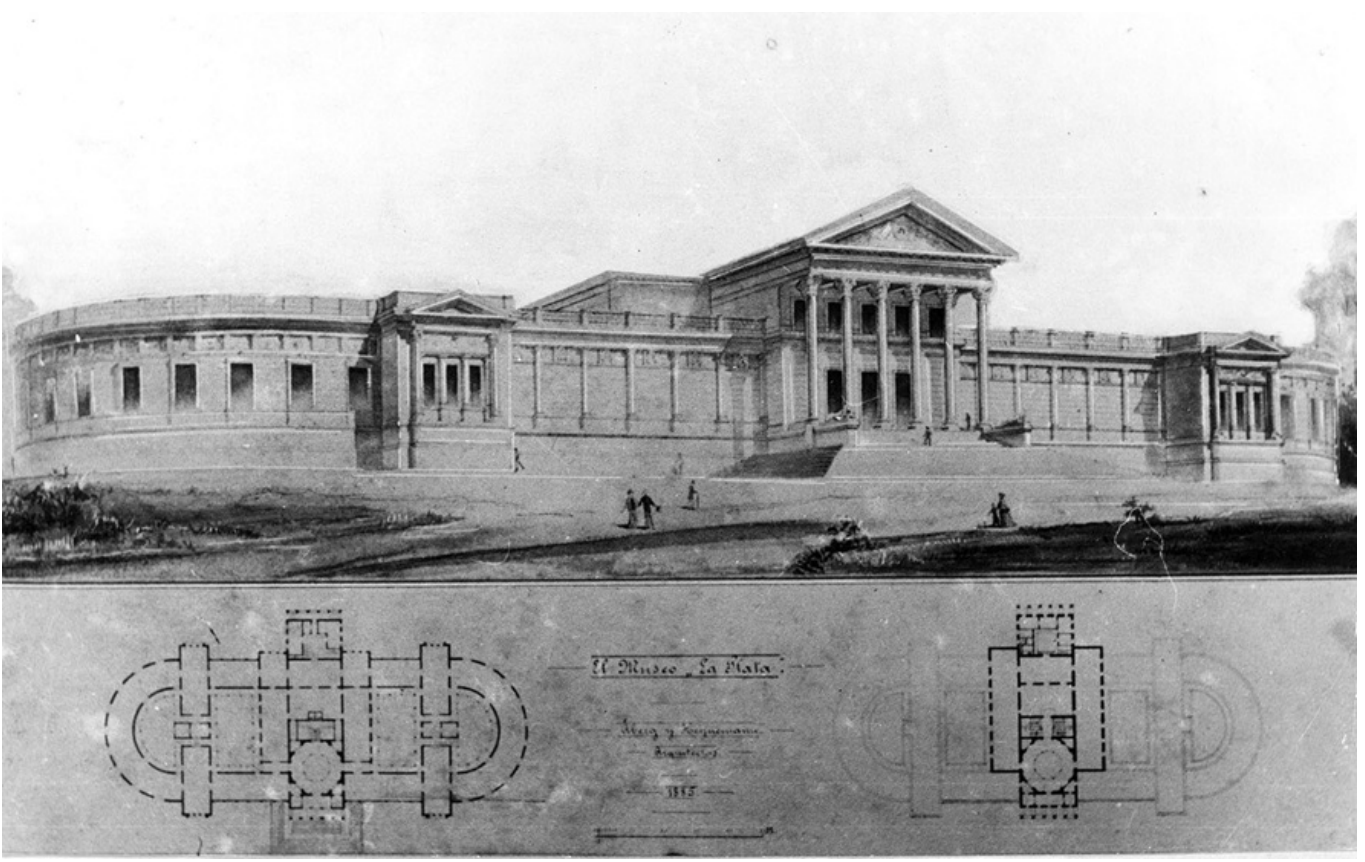




\section{Progetto di espansione di Krause}

Al fine di adattare l'edificio alla quantitá di pezzi da esporre e alla crescita dell'attività accademica che vi si svolgeva, in occasione del suo centenario, è stato realizzato uno dei progetti di intervento più significativi nella città di La Plata, ma che purtroppo non è mai stato realizzato. Questo progetto di espansione fu a carico di un gruppo guidato dall'architetto Vicente Krause, appartenente a una delle prime generazioni di architetti diplomati all'UNLP [4]. La proposta includeva l'aggiunta di un volume attraverso un giardino anulare sotterraneo che doveva circondare l'opera, riproducendo il suo principio d'ordine e allo stesso tempo consentendo l'ingresso di luce e aria nel sottosuolo. Nel progetto di Krause un sistema circolatorio centrale avrebbe collegato il museo preesistente e le aree di estensione, con l'uso di scale mobili, percorsi pedonali e la penetrazione della luce naturale lungo tutto il percorso verticale. Rispetto alla proposta progettuale presentata, Krause parla di un concetto diverso, utile per ripensare i modi di usare lo spazio: nel tempo è stato dimostrato che le funzioni determinanti per creare certi spazi variano in base al dinamismo della vita attuale, soprattutto in campo culturale [5]. Egli ha cercato di porre maggiore enfasi sulle aree strettamente legate allo spazio urbano, contribuendo all'incontro e all'integrazione con l'ambiente, questioni che erano considerate in passato secondarie. In uno dei suoi disegni Krause mette in relazione la sua idea progettuale con un gioiello prezioso, rivelando "L'idea di aggraffare come se il vecchio edificio fosse una pietra preziosa da proteggere" [Krause 1998, p. 61]. Questa operazione potrebbe essere interpretata come una violazione dei principi accademici, poiché si viene a generare un vuoto che sembra collocare il classico edificio emergente nell'aria, ma anche si rimanda ad un edificio medievale, il cui fossato funge da barriera protettiva per le mura (fig 5).
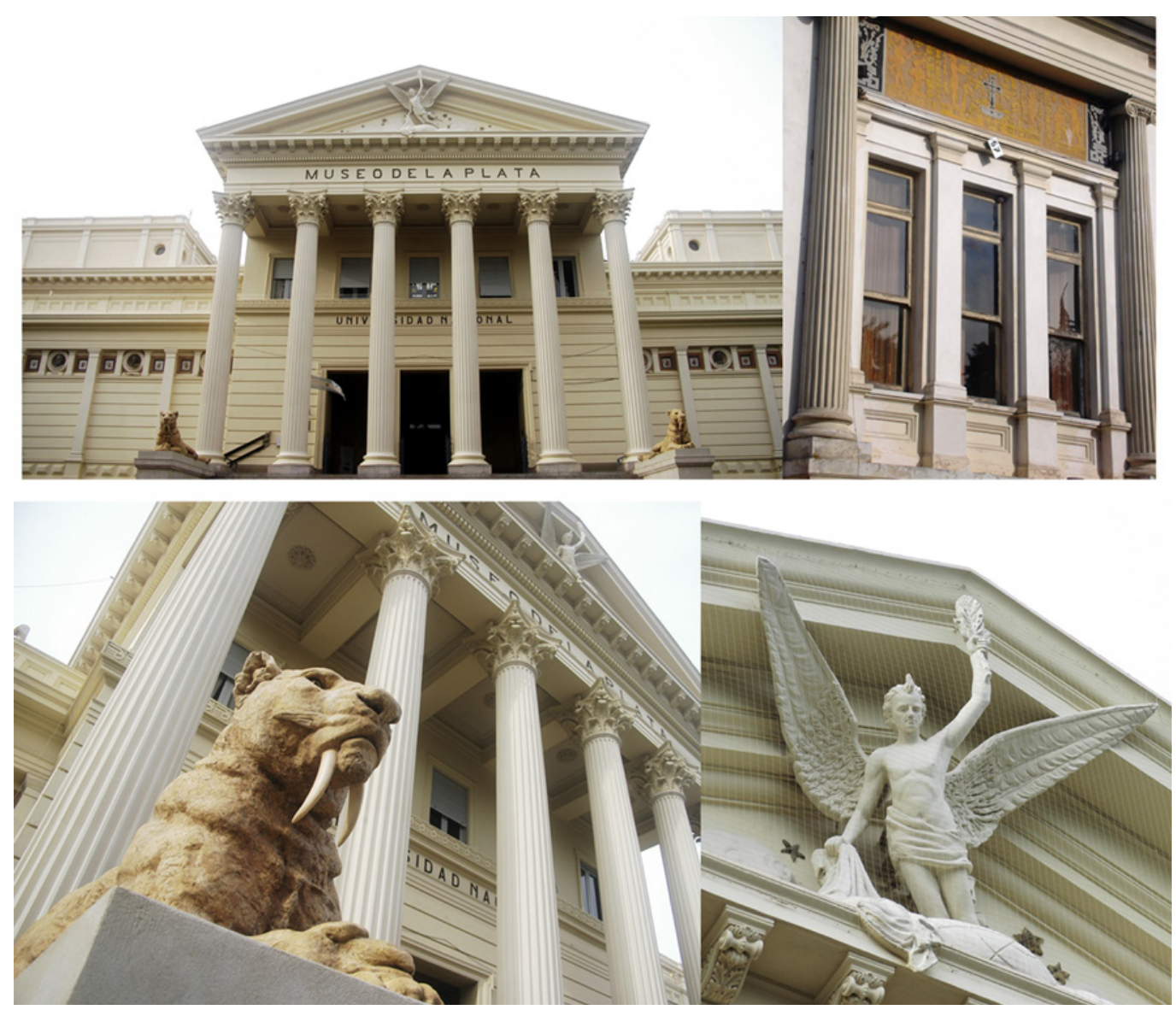


\section{Analisi tra disegno e progetto}

Avendo chiaro come obiettivo la comunicazione dell'idea di progetto di Krause, relativa all'ampiamento del Museo delle Scienze Naturali si è scelto di raccontare attraverso la rielaborazione del linguaggio grafico, un progetto non realizzato e solo immaginato, caratterizzato da una potente qualità architettonica e spaziale. Si è deciso di lavorare inizialmente con gli 'schizzi' autografi dell'autore e, successivamente, con rappresentazioni bidimensionali e tridimensionali. Essenziale è il ruolo del disegno e la scelta delle diverse modalità grafiche a seconda dell'aspetto progettuale che si sceglie di trattare. Nella fase iniziale ad essere considerato è lo schizzo di progetto, modalità incisiva per tradurre l'idea sul foglio di carta in modo rapido ed istintivo. Fin dagli schizzi si percepisce una chiara ripetizione ritmica degli spazi e l'utilizzo di una netta proporzione che instaura un dialogo tra nuovo ed esistente, incorporando nuove tecnologie costruttive con la trama dei materiali (figg. 6, 7). Allo schizzo affidiamo la registrazione degli elementi salienti di un luogo e la comunicazione dell'aspetto emozionale dell'idea. Si è proceduto inizialmente con la realizzazione di un montaggio degli schizzi di Krause attraverso una loro disposizione tridimensionale rispetto al progetto di base (fig. 8).

Obiettivo principale di questa immagine è quello di far risaltare l'idea progettuale, in questo modo non solo il singolo disegno assume una precisa collocazione spaziale ma tutti gli schizzi possono essere riconnessi e quindi letti contestualmente, costruendo così un'immagine complessiva di quello spazio immaginato dall'autore. Nell'elaborato si è scelto di applicare una diversa cromia per denunciare il fatto che sia stata effettuata una rilettura critica interpretativa. L'immagine che ne deriva unisce scorci di uno spazio solo immaginato ma che ora è possibile osservare nell'insieme dell'opera. L'analisi grafica del progetto è proseguita con un "esploso assonometrico" realizzato utilizzando rappresentazioni di diversa natura quali piante bidimensionali ed un'immagine tridimensionale dell'edificio (fig. 9). Nell'esploso viene posizionata la pianta del piano terra dell'edificio attuale per poi riportare, con differente cromia, l'ampliamento del progetto di Krause. Partendo dal basso è stata inserita la pianta dell'edificio attuale, e poi, verso l'alto è stato aggiunto il disegno in pianta. Risulta evidente l'aggiunta del grande 'anillo' progettato dall'autore.

\section{Studio su un'architettura 'scavata'}

E' opportuno studiare l'edificio focalizzando l'attenzione anche sul suo aspetto formale: il Museo presenta un'imponente forma di sviluppo rettangolare con due semicerchi negli estremi, dunque l'idea del ciclo continuo e della fruizione degli spazi viene marcata nel

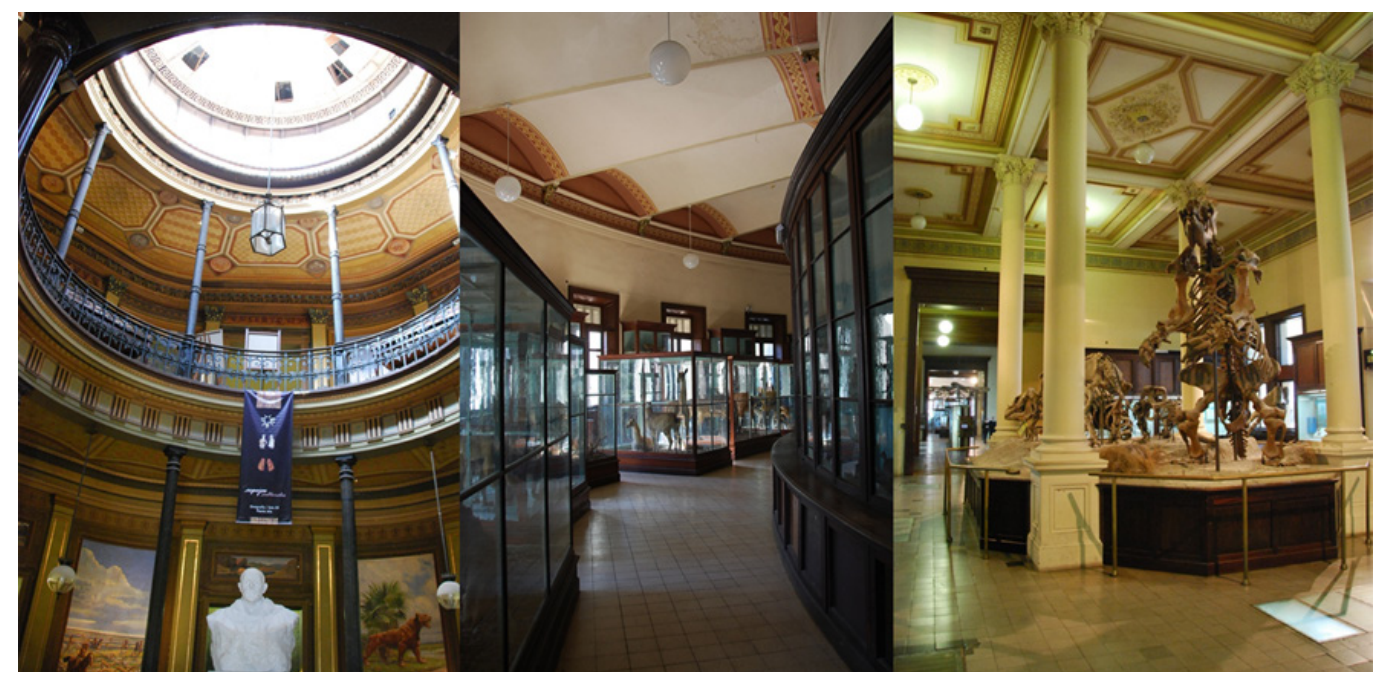


progetto originale ma fortemente enfatizzata nel progetto di ampliamento proposto da Krause.Volendo preservare il 'Bosche' (la grande presenza di verde che da sempre circonda l'edificio) l'unico ampliamento possibile poteva essere effettuato sottraendo volumi ipogei, ricavando nuovi spazi aggiuntivi ma senza intaccare troppo la percezione esterna dell'edificio, quasi come a voler 'scolpire' per non invadere il paesaggio naturale. L'opera di Krause è un'architettura di sottrazione, un volume (quasi un antico fossato) scavato intorno all'edificio esistente, dove si aggiunge un secondo volume ma nascosto, al quale vengono attribuite diverse funzioni spaziali e di fruizione del Museo. Un ampliamento esternamente quasi silente ma che all'interno si impone in modo dirompente cambiandone gli schemi distributivi, unendo ambienti mai uniti prima. Questo fa riflettere anche su quanto sia necessario adeguare il progetto al tempo in cui esso esiste: c'era la necessità di aggiungere nuovi ambienti di lavoro e di esposizione, stabilendo nuove strategie didattiche ed interattive, collegandole all'esterno, all'intorno (fig. I0).

Fig. 5. Schizzi a mano libera realizzati a matita e carboncino dell'idea progettuale dell'architetto V. Krause.

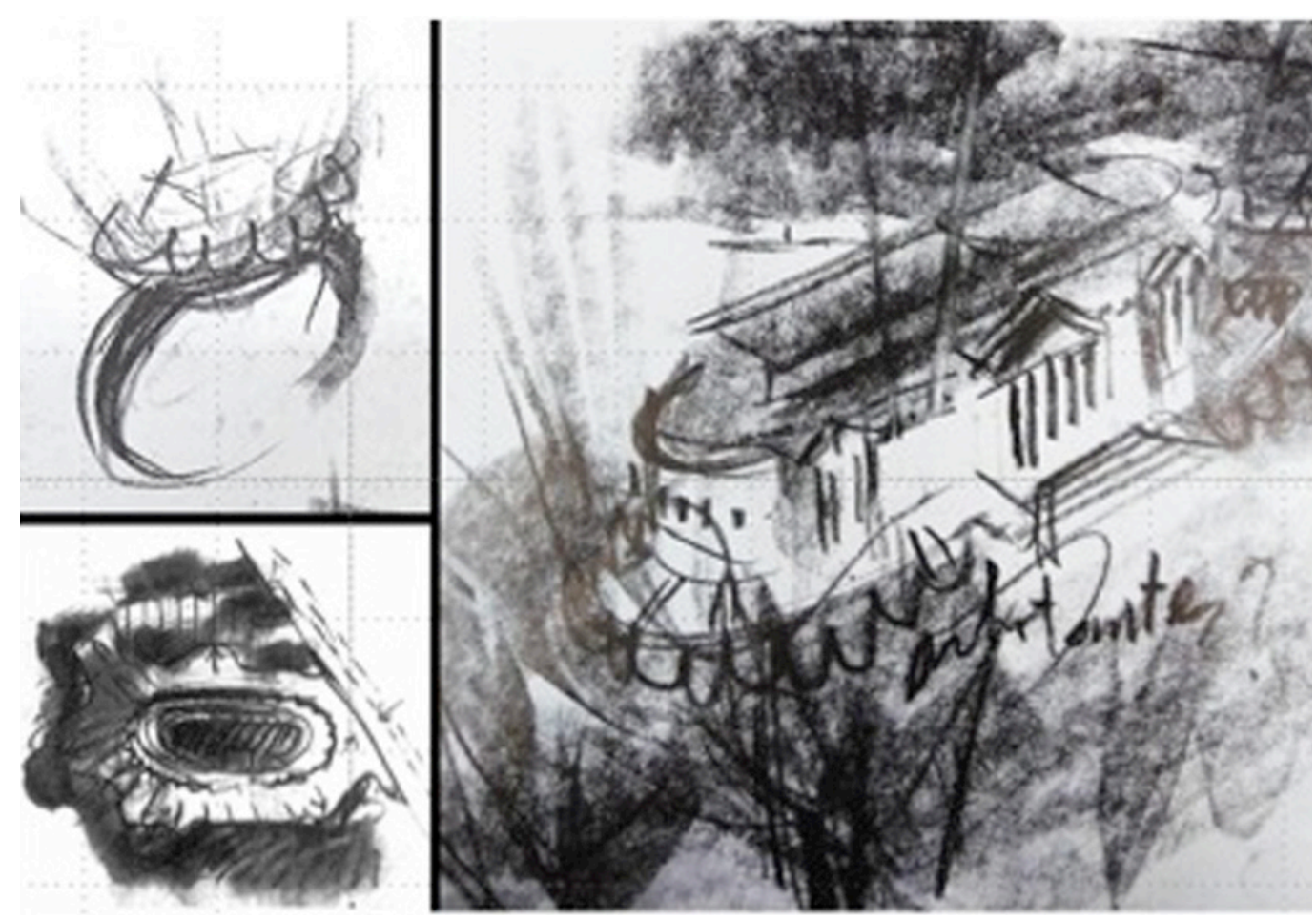

Krause nel suo progetto ricalca il perimetro esistente dell'edificio e sceglie consapevolmente di effettuare un offset della forma - geometricamente ben definita - verso l'esterno, creando un doppio anello in un alternanza di volumi aperti e chiusi intorno all'edificio principale. Si è rivelato utile all'analisi che segue considerare il progetto di Krause nell'interezza del suo impianto bidimensionale planimetrico, andando a sovrapporre alla planimetria esistente l'impronta del volume del progetto non realizzato (indicato in rosso). I rapporti proporzionali tra le parti, sia in pianta che in sezione, dimostrano come l'espansione orizzontale prevalga su quella verticale, il tutto a servizio della fruizione dello spazio, che avvolge l'intera base dell'edificio. II negativo - inteso come sottrazione di volume - del percorso anulare intorno all'edificio va ad aggiungere preziosità al progetto, gli stessi schizzi, sia generali che di dettaglio in cui Krause inserisce addirittura personaggi di fantasia (come scimmie antropomorfe e astronauti) sottolineano lo 'svuotamento' per la creazione di nuovi volumi e nuove necessità (fig. I I). 


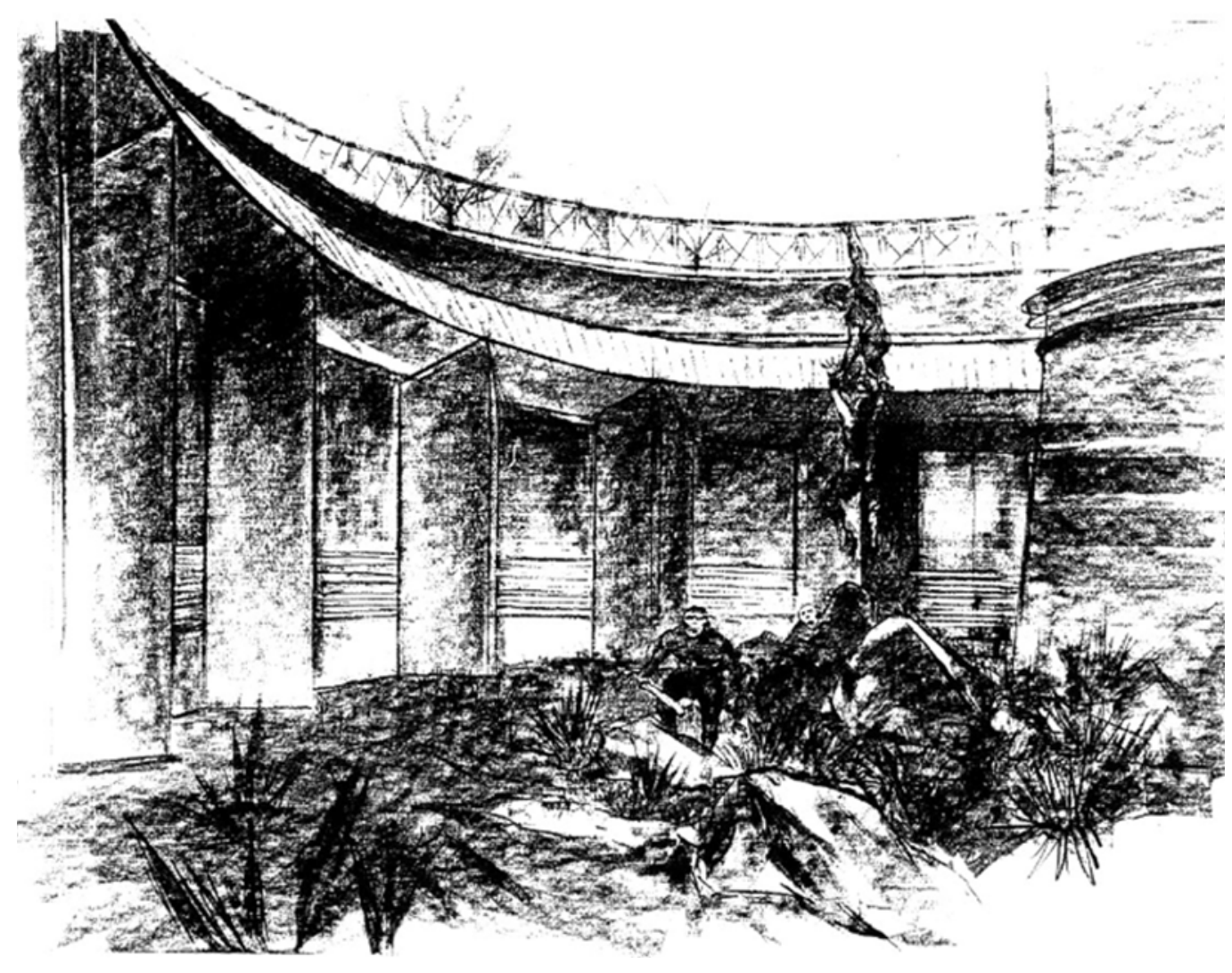

Figg. 6, 7: Due importanti schizzi di V. Krause maniera proro in le peculiarità del suo progetto.

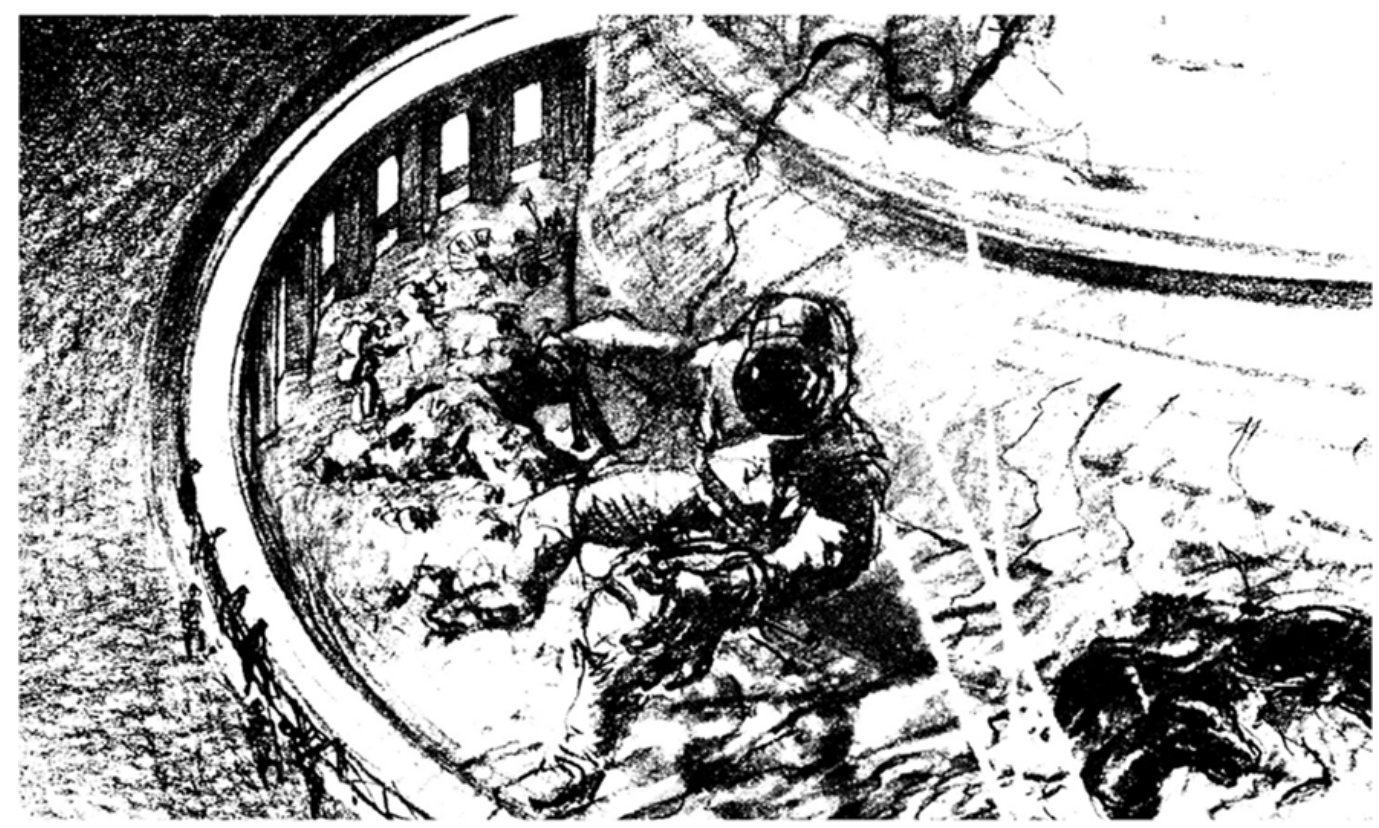



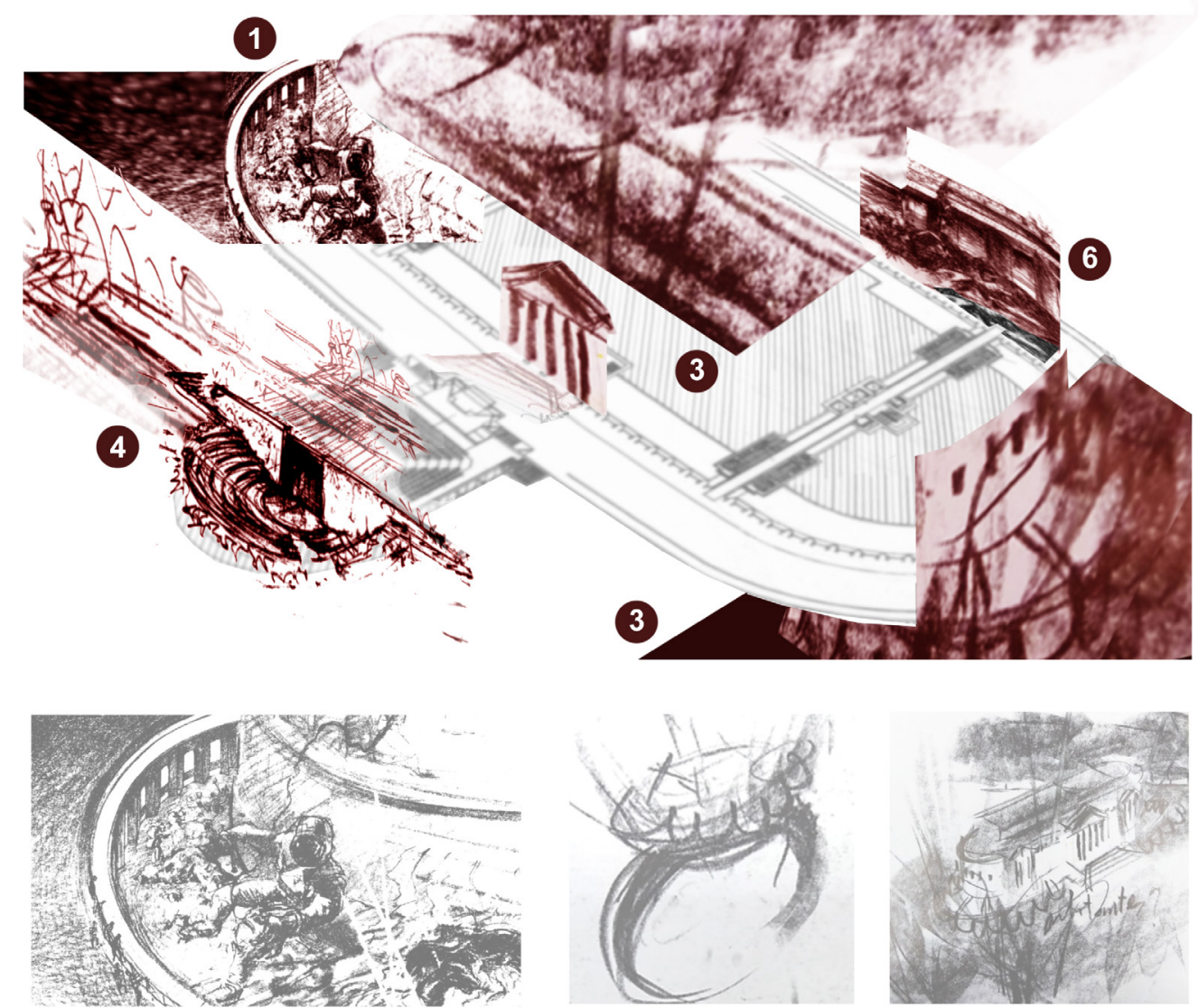

Fig. 8. Inserimento schizzi del progeto di Krause nella

planimetria di progetto in vista tridımensionale assonometrica.

1 EL ANILLO DRAWING BY VICENTE KRAUSE

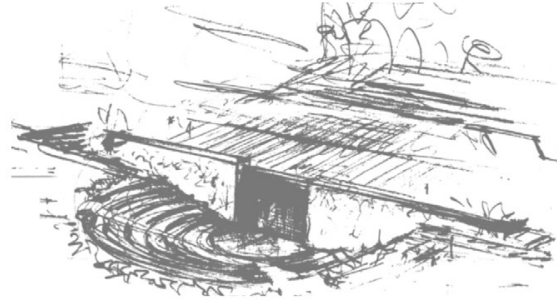

(4) DRAWING BY VICENTE KRAUSE
(2) AMPLIACION DEL MUSEO DRAWING BY V. KRAUSE
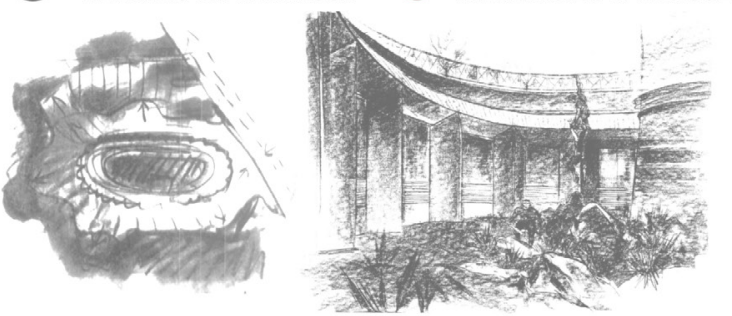

(5) LA IDEA/EL DETALLE

(6) EL ANILLO DRAWING BY V. KRAUSE DRAWING BYV. KRAUSE 


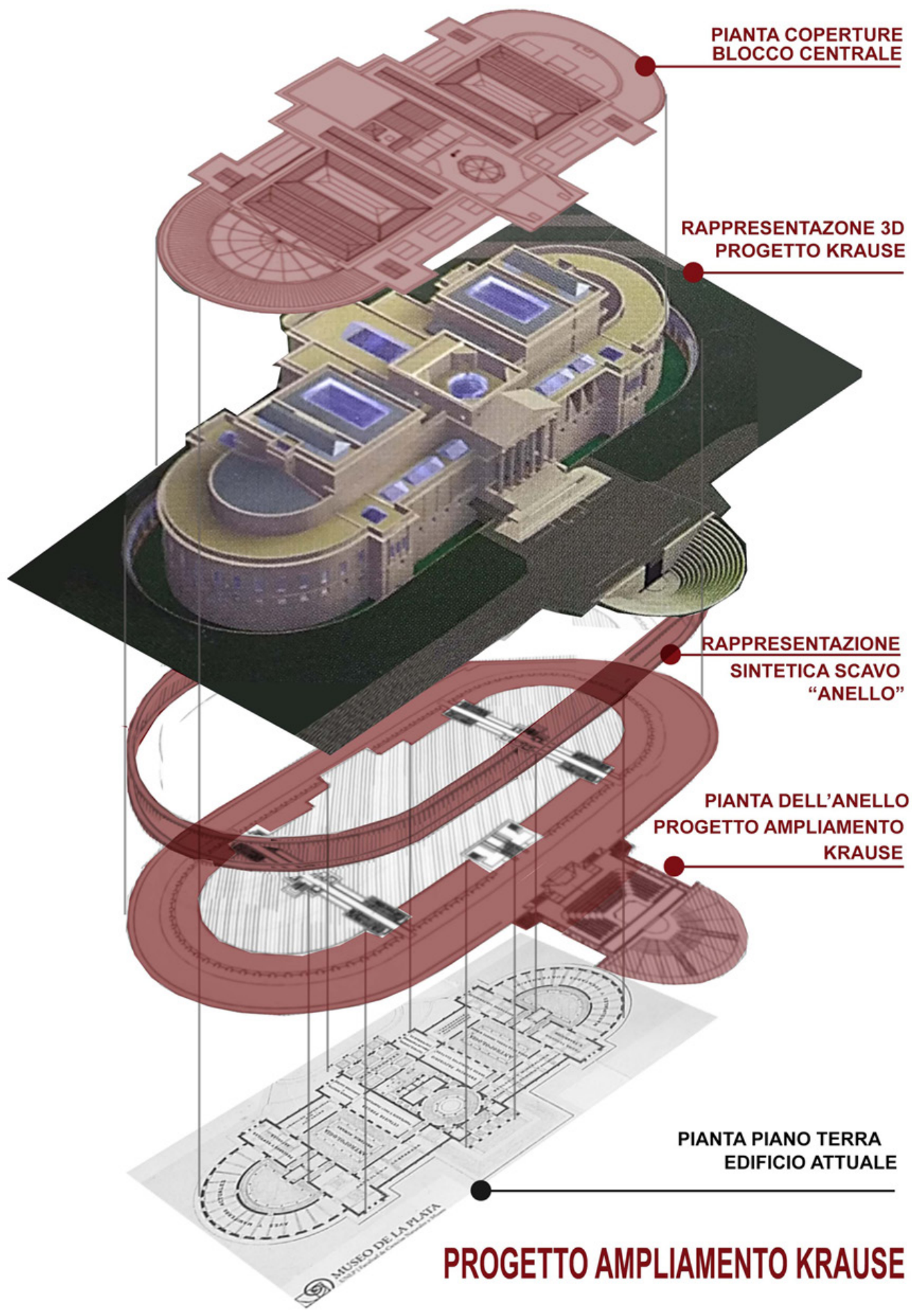


Fig. 10. Analisi formale planimetrica del progetto di ampliamento inserito nell'attuale planimetria, sia in pianta che in sezione sono evidenti i rapporti proporzional tra le parti.

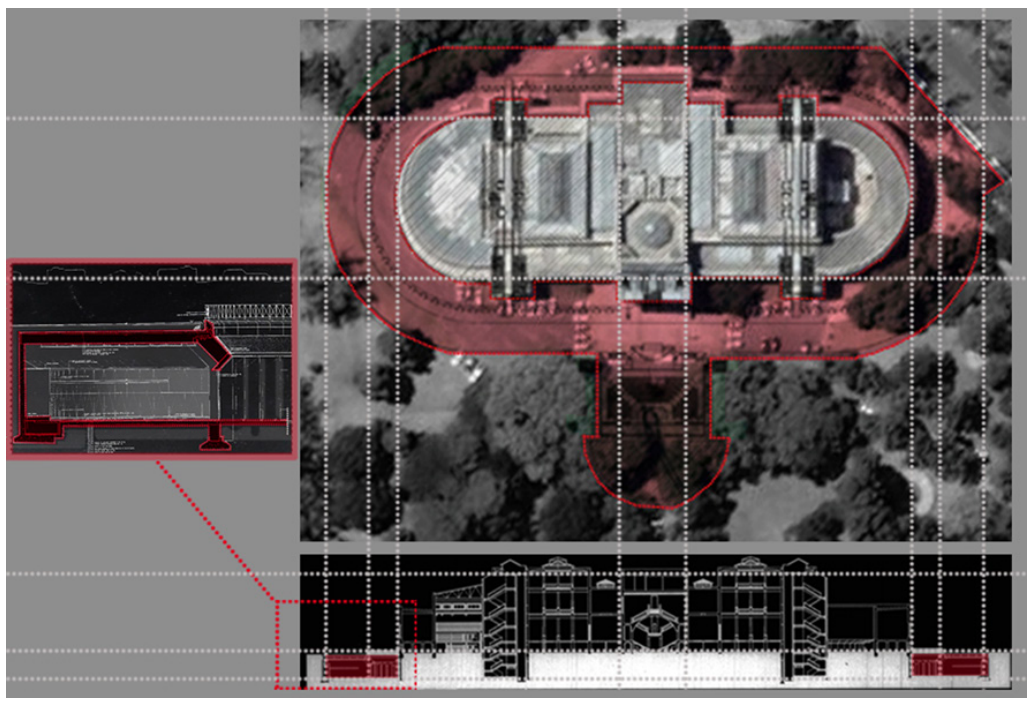

\section{Conclusioni}

Per la conservazione dell'immagine di un luogo è essenziale la raccolta di tutta la documentazione grafica di archivio, soprattutto se il soggetto è un edificio di notevole valore storico culturale. In questo caso la salvaguardia e la connessione delle fonti storiche ad un reale edificio assume maggiore rilievo in quanto riguarda qualcosa che mai è esistito e che potrebbe andare perduto. Essenziale è quindi che nessuna traccia e testimonianza riguardante il patrimonio culturale (in questo caso immateriale) venga dimenticata. II passo in più che è stato fatto in questo caso è stato, oltre alla raccolta delle fonti, quello di metterle a sistema, analizzarle attraverso la realizzazione di immagini grafiche complesse, con il fine di fornire al visitatore un ritratto a $360^{\circ}$ del bene architettonico ed in particolare di una sua possibile evoluzione mai eseguita.

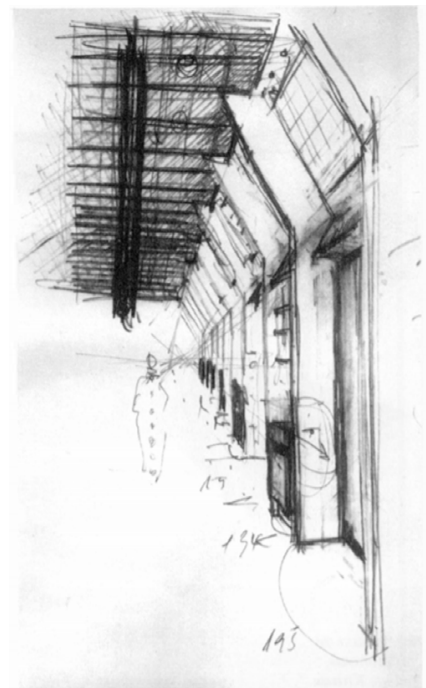

Fig. I I. Schizzo di dettaglio diV Krause della parte interna dell' 'anillo'.

\section{Note}

[1] Anche se il presente contributo è stato redatto in stretta collaborazione tra oli autori, ai paragrafi Introduzione e Conclusioni si è maggiormente dedicata Emanuela Chiavoni, al paragrafo Origine del museo si è maggiormente dedicata Maria Belen Trivi, il paragrafo Progetto di espansione è stato curato con maggiore attenzione da Fabiana Carbonari, mentre al paragrafo Analisi tra disegno e progetto si è dedicata in maggior misura Giulia Pettoello, infine al paragrafo "Studio su un architettura scavata" si è maggiormente dedicata Francesca Porfiri. A Fabiana Carbonari e a Maria Belen Trivi spetta la selezione critica dei numerosi disegni e immagini di archivio e la realizzazione di foto attuali dell'interno e dell'esterno dell'edificio, mentre le Figure I e I0 sono elaborazioni di Francesca Porfiri e le Figure 8 e 9 di Giulia Pettoello. 
[2] Questo argomento costituirà parte integrante dell'Osservatorio digitale interattivo sull'identità culturale del patrimonio italo-argentino attualmente in via di definizione.

[3] La proposta per questo tipo di pianta in America Latina, fu fatta, prima, dal professor Albert Gaudry e fu ispirata alle nuove gallerie paleontologiche del Museo di Scienze di Parigi.

[4] Va notato che oltre alle funzioni espositive dei pezzi del museo e alle funzioni accademiche che vi si svolgevano dopo il suo passaggio all'UNLP, vi fu anche incorporata l'attività della Facoltà di Scienze Naturali e Museo, creata nell'anno 1949.

[5] Krause sostiene che: "Il concetto di funzione ambigua dà origine a un'organizzazione strutturale meno espressiva dei contenuti dello spazio interno - senza dubbio - ma più espressiva e orientata meglio nel senso di contribuire allincontro e allo sviluppo di un 'carattere urbano' definito"' [Krause 1997].

\section{Riferimenti bibliografici}

Carbonari Fabiana, Chiavoni Emanuela, Porfiri Francesca (2019). Interactive Digital Observatory on the Cultural Identity of Italo-Argentine Heritage. In SCIRES-IT, vol. 9, Issue 2, Caspur-Ciber Publishing, pp. I05-I I 4.

Chiavoni Emanuela, Porfiri Francesca (2019). Archivi, disegni e cultura, in Salgueiro Walter. La rapresentacion grafica de naturaleza tecnica. In Libro de actas, trabajos extensos, XVI Congreso Nacional de profesores de Expresion Grafica en Ingenieria, Arquitectura Y Carreras Afines, 3-4 ottobre 2019, Olavarria-Pcia. Buenos Aires, Tandil: Universidad Nacional del Centro de la Provincia de Buenos Aires. pp.98-102.

De Carlo Laura (20 I5). Metamorfosi dell'immagine urbana. Rappresentazione, documentazione, interpretazione, comunicazione. Roma: Gangemi editore.

Docci Mario (200 I). Le discipline del Disegno e la ricerca scientifica. In Disegnare, Idee Immagini, 43, pp. 3-6.

Chiavoni Emanuela, Pettoello Giulia, Diacodimitri Alekos (2018). La rappresentazione notturna della città. In Bombassei Elisa, Lucero Hernán, Capellari Fernando (a cura di). Campos, umbrales y poéticas del dibujo. Libro de Actase de Resúmenes: VII Congreso Internacional y XV Congreso Nacional del Profesores de Expresión Gráfica en Ingeníria, Arquitectura y Carreras Afines. Río Cuarto : UniRío Editora. pp. 300-307.

Carbonari Fabiana, Chiavoni Emanuela (20 I 8). The landscape of the Astronomical Observatory in La Plata, Argentina: form, geometry and colour. In Salerno Rossella (a cura di). Rappresentazione materiale/immateriale. Drawing as (in)tangible representation. Atti del $40^{\circ}$ Convegno internazionale dei Docenti delle Discipline della Rappresentazione. Milano 13-I4- I5 settembre 2018. Roma: Gangemi Editore, pp. I019-1026.

Carbonari Fabiana, Chiavoni Emanuela (2017). II patrimonio culturale della città di La Plata in Argentina: analisi e valorizzazione. In La città creativa. Spazi pubblici e luoghi della quotidianità, Consiglio Nazionale Architetti Pianificatori Paesaggisti e Conservatori (CNAPPC), pp. 655-665

Carbonari Fabiana, Chiavoni Emanuela, Docci Mario et al. (2016). Obras realizadas por los constructores italianos en La Plata entre 1918 y 1945. Arquitectura, análisis y dibujo. In Bertocci Stefano, Bini Marco (a cura di). Le ragioni del Disegno. Pensiero, Forma e Modello nella Gestione della Complessità. Atti del $38^{\circ}$ Convegno internazionale dei Docenti delle Discipline della Rappresentazione, Firenze |5-I6-I7 settembre 20 |6. Roma: Gangemi Editore, pp. I45-I50.

Gandolfi Fernando, Gentile Eduardo, Carbonari Fabiana (collab.). (2008). GAL Guías de Arquitectura Latinoamericana. La Plata. Buenos Aires: Edi. Clarín.

De Grandis Maria Belén (2019).Vicente Krause. In Anales del IAA, pp. I7I - 190.

Migliari Riccardo (2004). Disegno come Modello. Roma: Edizioni Kappa.

Morlacchi Marcella (2008). Il libro del Disegno. Roma: Gangemi Editore.

Krause Vicente (1997). Tocar lo intocable. La ampliación del Museo de Ciencias Naturales de La Plata. 47 al fondo, 22-29.

Krause Vicente (1998). Ampliación del Museo de Ciencias Naturales de La Plata. In Ambiente, pp. 58-65.

\section{Autori}

Fabiana Carbonari, Universidad Nacional de La Plata, fabianacarbonari@yahoo.com.ar

Emanuela Chiavoni, Sapienza Università di Roma, emanuela.chiavoni@uniromal.itgiulia

Giulia Pettoello, Sapienza Università di Roma, giulia.pettoello@uniromal.it

Francesca Porfiri, Sapienza Università di Roma, francesca.porfiri@uniromal.it

María Belén Trivi, Universidad Nacional de La Plata

Per citare questo capitolo: Carbonari Fabiana, Chiavoni Emanuela, Pettoello Giulia, Porfiri Francesca, Trivi María Belén (2020). In Arena A., Arena M. Brandolino R.G., Colistra D. Ginex G. Mediati D. Nucifora S., Raffa P. (a cura di). Connettere. Un disegno per annodare e tessere. Atti del $42^{\circ}$ Convegno Internazionale dei Docenti delle Discipline della Rappresentazione/Connecting. Drawing for weaving relationships. Proceedings of the 42th International Conference of Representation Disciplines Teachers. Milano: FrancoAngeli, pp. I880-1901. 


\title{
Project and Memory. Drawings and Relationships for the Museum of Natural Sciences in La Plata
}

\author{
Fabiana Carbonari \\ Emanuela Chiavoni \\ Giulia Pettoello \\ Francesca Porfiri \\ María Belén Trivi
}

Abstract

Ever since the National University of La Plata - UNLP - was built in 1905 many studies have been conducted regarding its history, thematic orientation, illustrious graduates and architecture. Significant links exist between the visual ideas, academic policies and disciplinary fields that inspired its artistic products, especially if one considers the multifaceted influences and training of the persons involved. Given the above, and in order to consolidate its memory, this study will reflect on and disseminate the extensive cultural and scientific heritage of the Museum of Natural Sciences. Enhanced comprehension of the artefact was achieved by analysing several drawings which, executed using different mediums, testify to its evolution over the years. They reveal the link between the views and representations of the building and its rich museum heritage. While drawings of the original project illustrate the eclectic academic building designed by K. Heynemann and H. Äberg, this study focuses on the parts designed in the nineties, i.e., the modern additions by the first graduates of the Faculty of Architecture and Urban Planning (FAU-UNLP). One such graduate was Vicente Krause, an architect whose graphic experiments captured the identity of the building in question and who proposed a feasible enlargement which, regrettably, was never built.

Keywords

documentation, reproduction, virtuality, graphic experimentation, drawing.

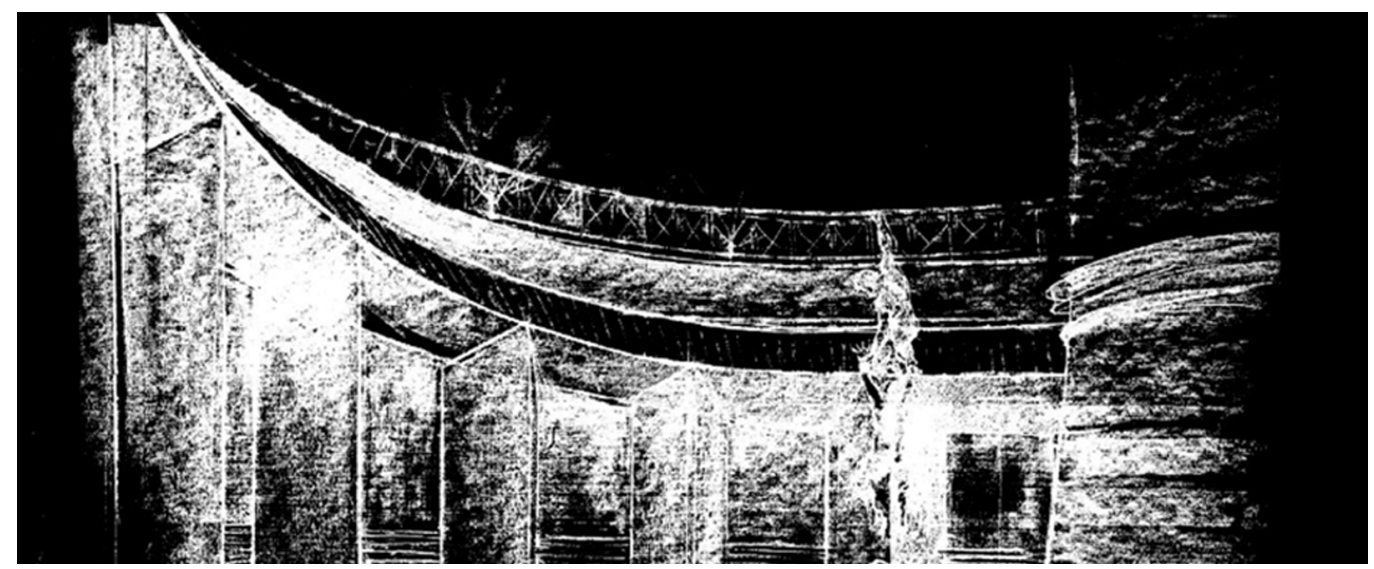




\section{Introduction}

This contribution focuses on relationships, considered as the desire to 'rebuild' the memory of an important building in the city of La Plata which, as in the weave of a fabric, is surrounded by narratives linked to projects executed during different periods in time. One enlargement project is particularly interesting; although never implemented, several drawings tell its story. The study used drawing to critically interpret the project and then couple it with a historical-documentary analysis; this led to the reconstructed identity of the project and its theoretical reconstruction [I]. The intent behind this historical, urbanistic, material, geometric and emotional communication mode is to 'combine' all available elements. The goal is to consolidate the memory of an immaterial cultural and scientific asset by systematising archival data, including unimplemented projects [2].

\section{Origins of the Museum}

The Anthropological and Archaeological Museum of Buenos Aires was built in 1877 to host the collections donated by Francisco Pascacio Moreno, later named lifetime director. After the federalisation of Buenos Aires and the foundation of the city of La Plata the museum was moved to the new provincial capital and renamed Museum of Natural Sciences of La Plata, the first building designed as a museum of the Republic of Argentina. The museum was designed in 1884 by the Swedish architect Henrik Äberg assisted by the German architect Karl Heynemann. The building became home to the 15,000 artefacts in the Anthological and Archaeological Museum of Buenos Aires. In 1906 the provincial government gave the new Museum and all its collections to the recently created National University of La Plata. All the academic and research activities were incorporated when collaboration began between the Faculty of Natural and Anthropological Sciences and the Faculties of Chemistry and Pharmacy. Thanks to the visionary ideas of Signor González, founder of the Universidad Nacional de La Plata, the museum was located in the bucolic setting of the "Bosche". González wished to link art and culture in the same urban district,

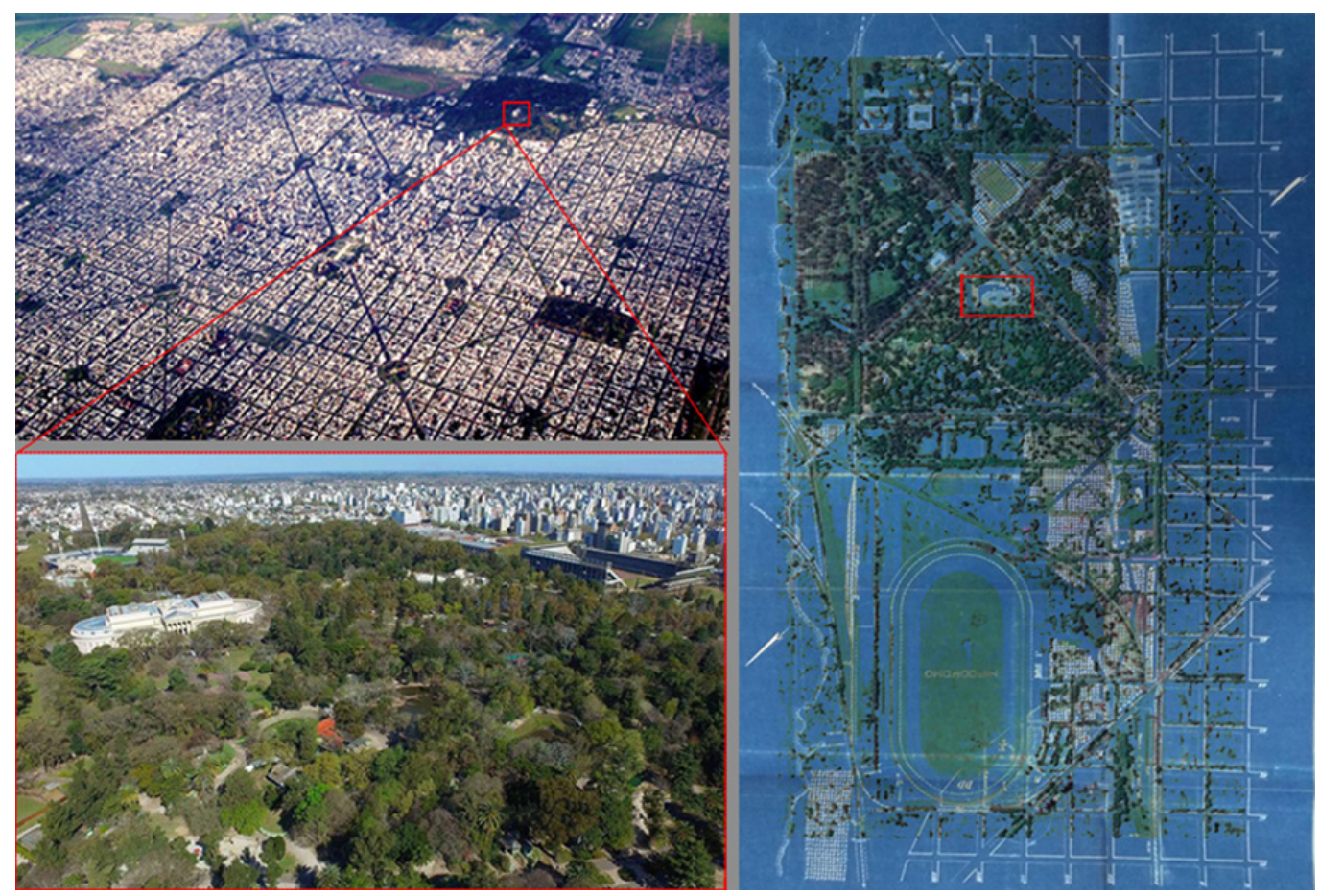


between the animal and vegetal kingdom, by placing the Museum, Zoo, Forest and Astronomical Observatory all in the same area (fig. I).

The building was designed based on academic postulates; it has a ring-shaped plan with two semi-circles at the extremities of the centre volume. The neoclassical style used by Äberg reflects the ideals to be achieved by the nascent society, coupled with several features of German academism. The building has three floors, including the basement and 'piano nobile' (fig. 2).

The building has a monumental portico with six, Schinkel-style Corinthian columns while its horizontal volume romantically contrasts the surrounding landscape. The design was influenced by several architectures, including the British Museum and National Gallery in London, the New Gallery of the Evolution in Paris, the Alte Pinakothek and the Glyptotek in Munich, the Altes Museum in Berlin, the Fitzwilliam Museum in Cambridge and the Smithsonian Institution in Washington. The overall concept is clearly an outer ring allowing visitors to explore the exhibitions in the basement and on the first floor [3]. The buildings symmetrically fulfil their functions; the building with the entrance and round centre hall is the most important focal point from which all the others depart. The façade has a windowless basement while the rhythm of the centre area is created by pilasters and panels with windows in the side sectors; the building is crowned by a continuous balustrade. The main Corinthian-style portico, located along the central axis of the building, contrasts with the two smaller lonic porticoes above which there are halls for different exhibits. It has very few ornaments and this was the first time pre-Columbian American motifs appeared on the façade of a public building in Argentina. The sculptural groups are by the Italian sculptor Víctor de Pol (fig. 3).

The interior is no less prestigious. Like the design solutions adopted in big nineteenth-century buildings, the ones employed here were based on the use of new materials such as iron and glass, and included the creation of special areas for all kinds of exhibits. The detailed study of the lighting and shapes created a stage-setting effect in which the contrast between the lighting and the exhibited artefacts plays a crucial role. The itinerary through these extremely expressive spaces is obvious and orderly; these spatial qualities were achieved by designing windows, light sources, dimensional variations, and the use of quality materials (fig. 4).

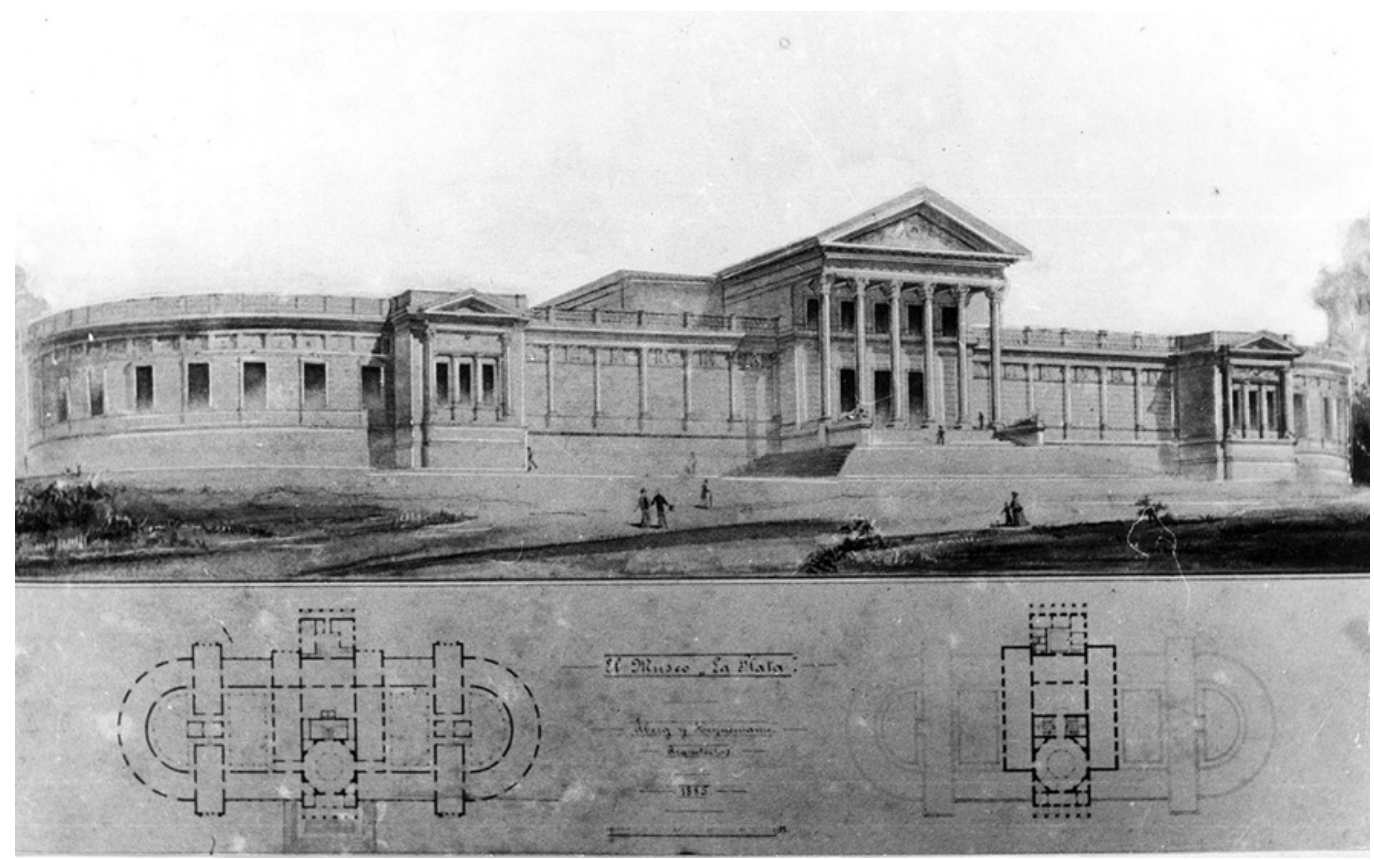




\section{Krause's enlargement project}

One of the most significant projects in the city of La Plata was drafted in the year of the building's centennial in order to provide more room for the numerous artefacts on display and the increase in academic activities. Unfortunately, however, it was never implemented. The project had been entrusted to a group headed by Vicente Krause, one of the first generations of architects who graduated from the UNLP [4]. The draft project included the addition of an exhibition area accessed through a ring-shaped sunken garden surrounding the whole ensemble; it was to reproduce its layout and, at the same time, allow light and air to enter the basement. Krause envisaged a central circulatory system that would use escalators and pedestrian paths to connect the existing museum to the enlargement and also allow natural light to enter the vertical itinerary. Compared to the project that was presented, Krause's focus was on a different concept, one that could be used to rethink the exploitation of space. Over the years there was growing evidence that the functions determining how to create certain spaces vary depending on the dynamism of contemporary life, especially as regards culture [5] He tried to place greater emphasis on areas more closely linked to urban space, ones which encouraged human interaction and integration with the environment. In the past these issues had been considered secondary. In fact in one of his drawings Krause compared his design idea to a precious piece of jewellery, revealing "an idea to bracket the old building as if it were a precious stone requiring protection" [Krause 1998, p. 61]. This idea could be interpreted as a violation of academic principles since it creates a void and seemingly launches the classical building into the air, but it is also reminiscent of a medieval building with a moat acting as a protective barrier around its walls (fig. 5).
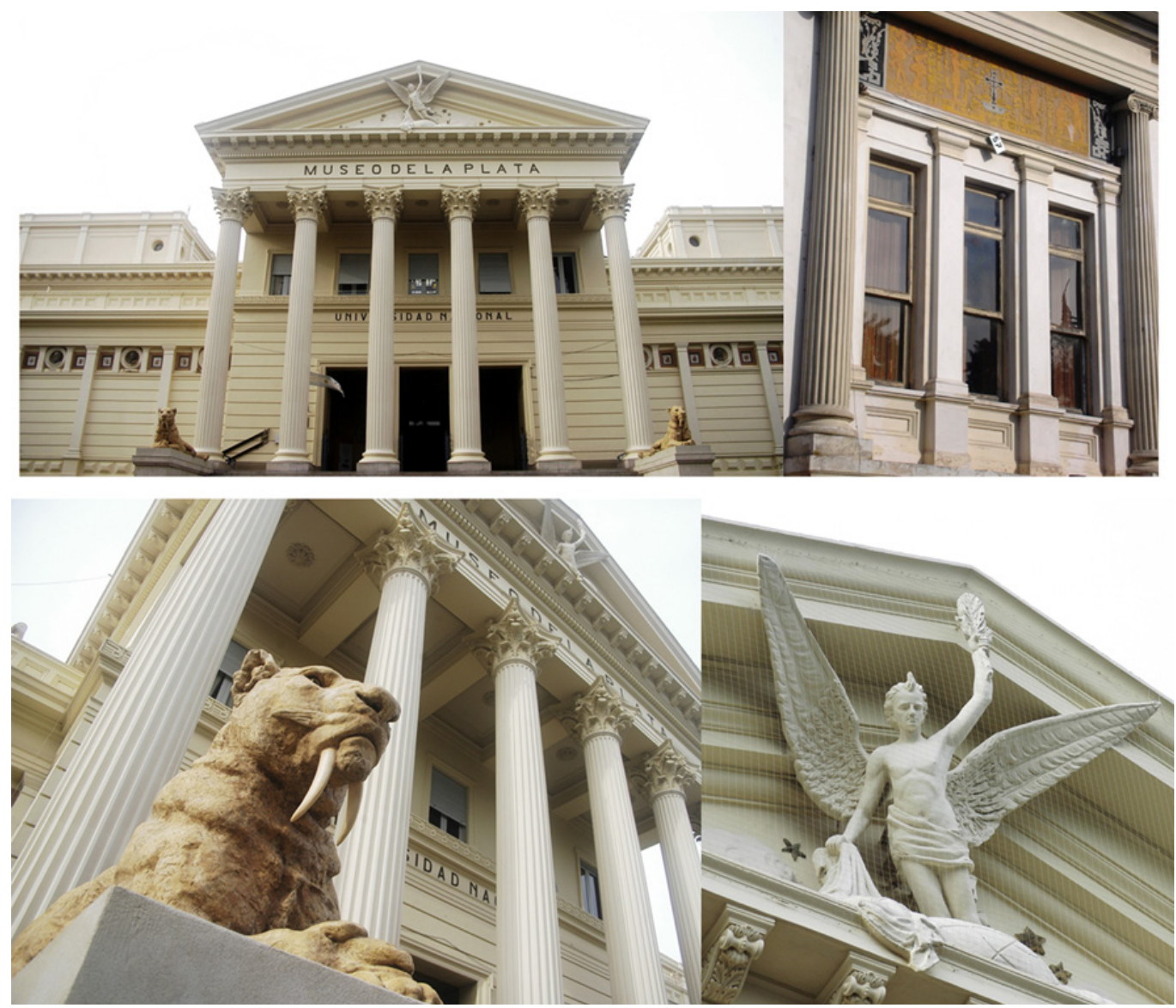


\section{Analysis of the drawing and project}

The objective of the study was to clearly communicate Krause's design idea regarding the enlargement of the Museum of Natural Sciences; a decision was taken to illustrate it by re-elaborating the graphic language of the project with its powerful architectural and spatial quality, designed on paper but never built. The initial focus was on Krause's "sketches" and only afterwards on two-dimensional and three-dimensional representations. Drawing was a crucial tool and so was the choice of graphic mode which depended on what design aspect one wished to illustrate. The design sketch was considered first; this is an insightful method to rapidly and instinctively represent the idea on a piece of paper. Starting with the sketches, what became immediately evident was a rhythmic repetition of the spaces and the use of a strict proportion; it created a dialogue between what existed and the new addition, incorporating new building technologies within the weave of the materials (figs. 6, 7).

The sketch was used to record the important elements of the place and communicate the emotions behind the idea. Krause's sketches were initially assembled by arranging them three-dimensionally compared to the first project (fig. 8).

The main purpose of this image is to highlight the design idea; not only does each drawing occupy a precise spatial area, but all the sketches can be simultaneously linked and interpreted. The end result is an overall image of the space imagined by Krause. Different colours were used to emphasise the fact we critically reinterpreted the sketches and design. The ensuing image merges bits of an imagined space that can now be seen as part of the ensemble. The graphic analysis of the work continued with an 'exploded axonometric view' pieced together using different kinds of representations, including two-dimensional plans and a three-dimensional image of the building (fig. 9). The exploded view starts with the plan of the ground floor of the current building and then, in different colours, Krause's enlargement project. The addition of the big 'anillo' designed by Krause is easy to identify.

\section{Study of an "excavated" architecture}

It was important to also focus on the formal appearance of the building: the imposing rectangular shape of the Museum with two semicircles at the extremities reflects the concept of a continuous cycle while fruition of the spaces is underscored in the original project but emphasised even further in Krause's enlargement project. Since Krause wished

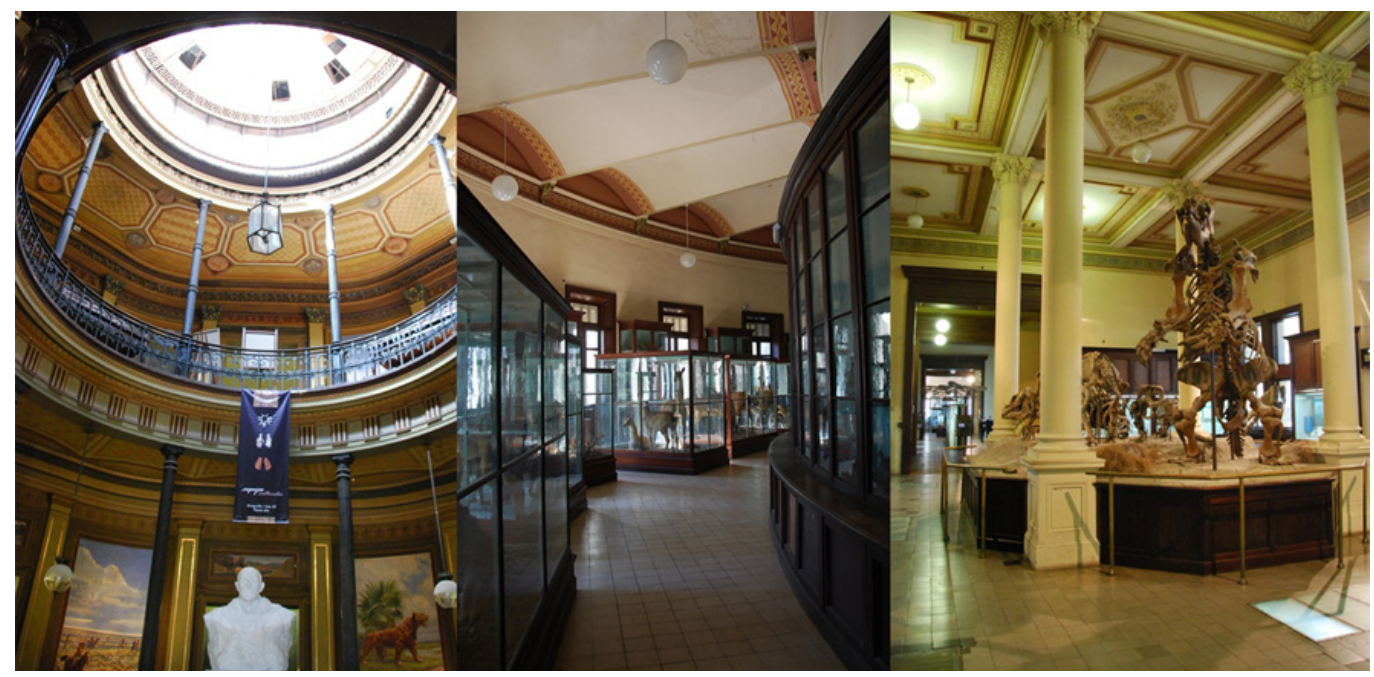


to preserve the 'Bosche' (the big green area that had always surrounded the building) the only possible enlargement was to create underground areas, adding more spaces but without damaging perception of the building's exterior; it was a way to 'sculpt' the landscape without invading it. Krause's proposal involves subtraction, excavating an area around the building (almost like an ancient moat) where another hidden building could be added; this building would play several spatial roles and provide access to the Museum. It was an almost silent external enlargement, but one which inside would radically change the layout, connecting halls and rooms which had hitherto been separate. This should make us reflect on how important it was for the project to satisfy contemporary needs: new work areas and exhibition halls were required and new didactic and interactive strategies had to be developed and linked to the exterior and surroundings (fig. 10).

In his project Krause closely follows the building's exterior and consciously chooses an 'offset' of the shape - geometrically well defined - towards the exterior, creating a double

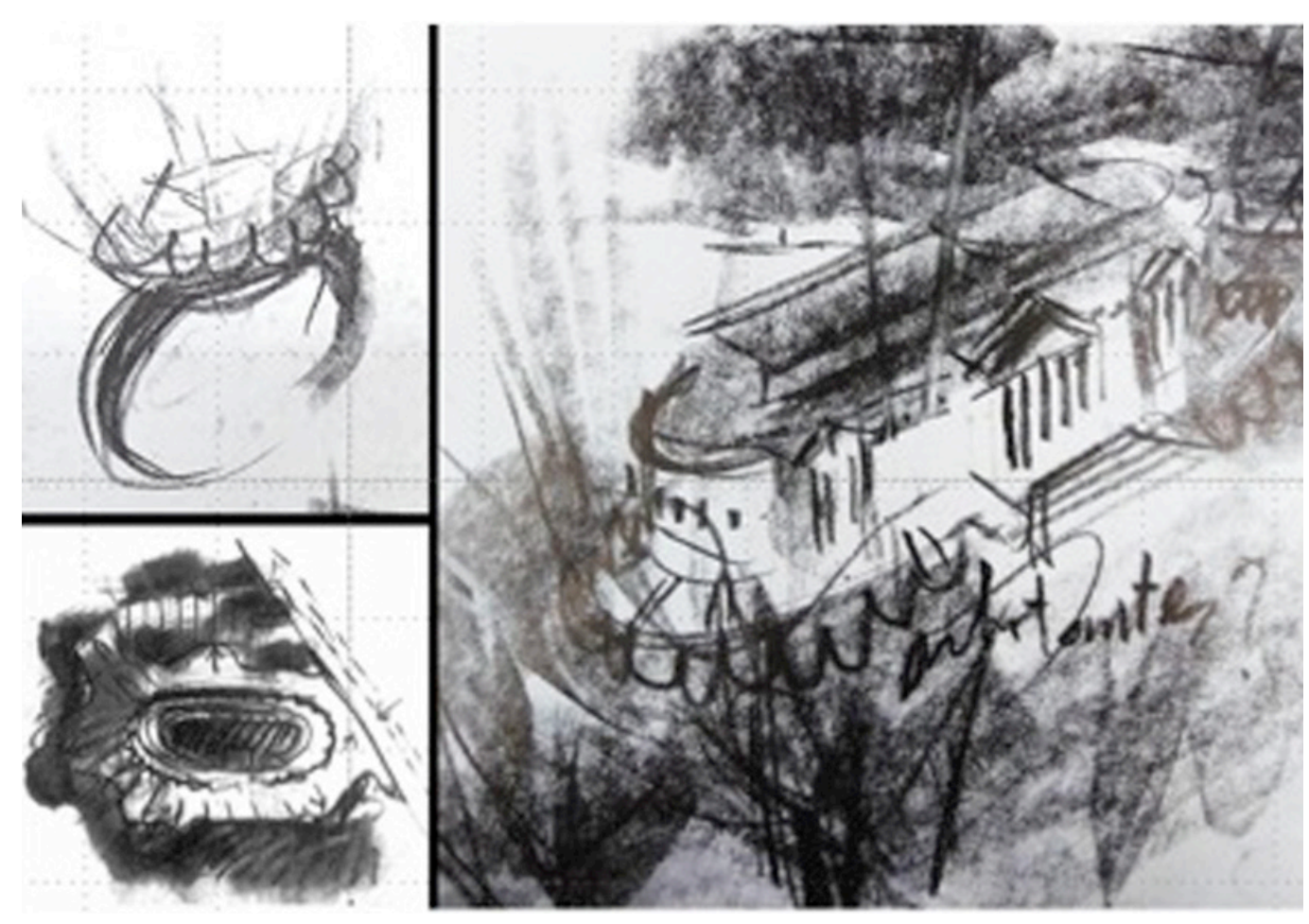

ring of alternate open and closed spaces around the main building. For the next part of the analysis it was useful to consider the whole two-dimensional planimetric layout of Krause's project, superimposing the unimplemented design (in red) on the existing plan. The proportional ratios between the parts, in plan and section, demonstrate how the horizontal enlargement prevails over the vertical enlargement so as to exploit the space around the base of the building. The project is enhanced by the negative space - considered as the subtraction of volume - of the ring-shaped path around the building. In his general and detailed sketches Krause even inserts imaginary characters (such as the anthropomorphic monkeys and astronauts), thus underscoring the 'emptying' required to create new spaces (fig. II). 


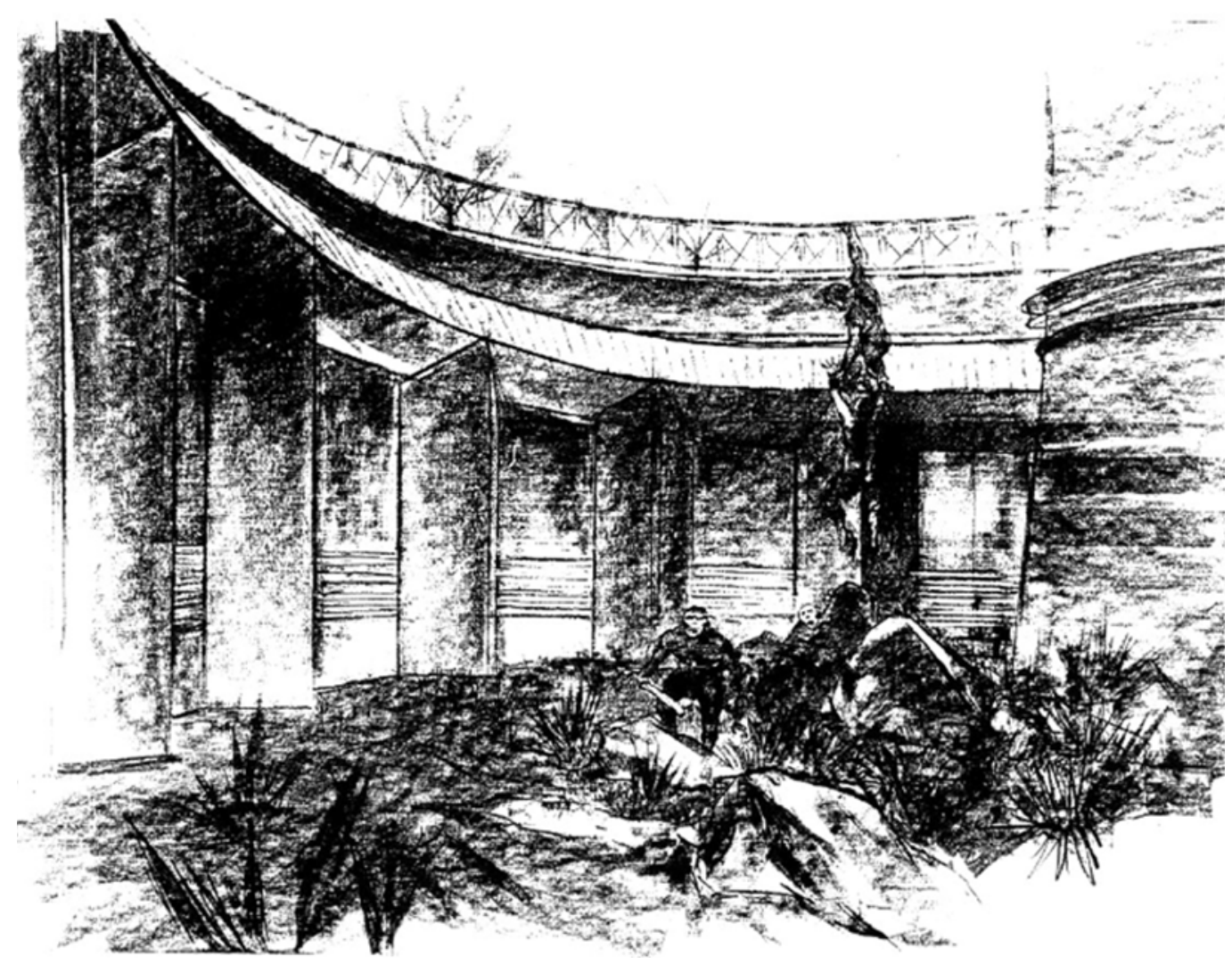

Figs. 6, 7. Two important and powerful sketches by V. Krause showing the project.

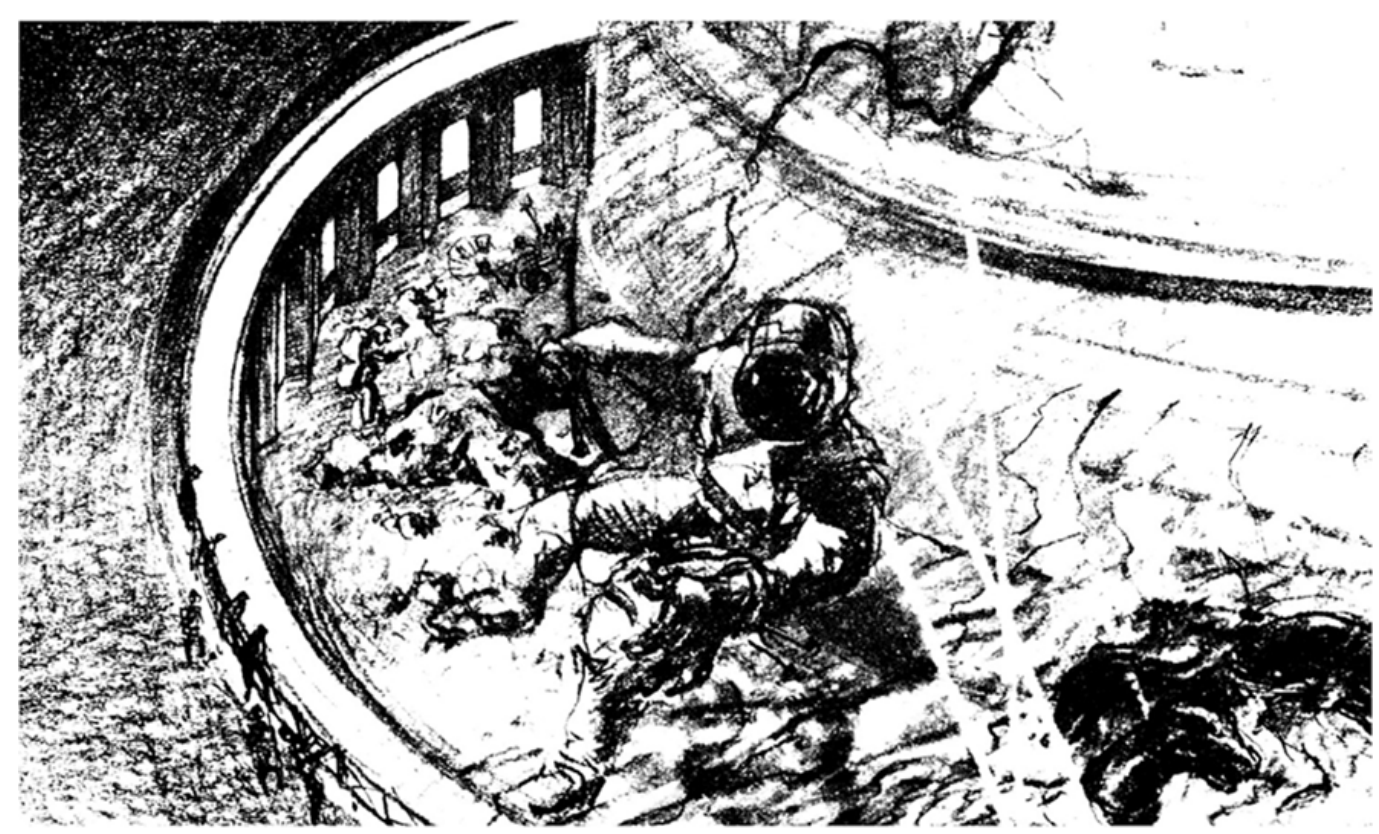



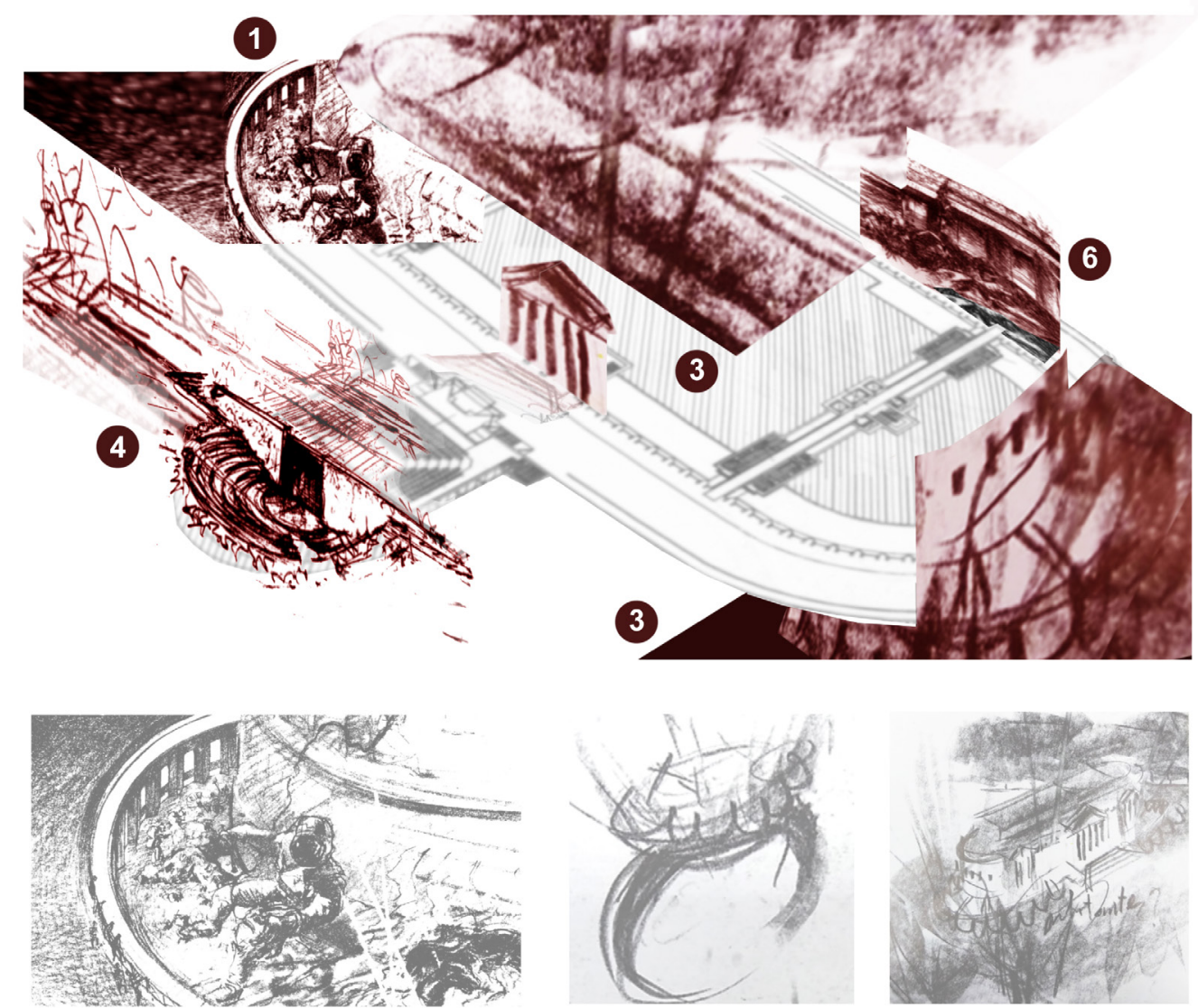

Fig. 8. Insertion of the sketches of Krause's project in the design plan (three-dimension axonometric view).

(1) EL ANILLO DRAWING BY VICENTE KRAUSE

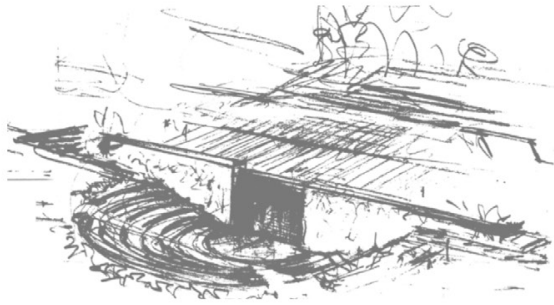

(4) DRAWING BY VICENTE KRAUSE
(2) AMPLIACION DEL MUSEO DRAWING BY V. KRAUSE
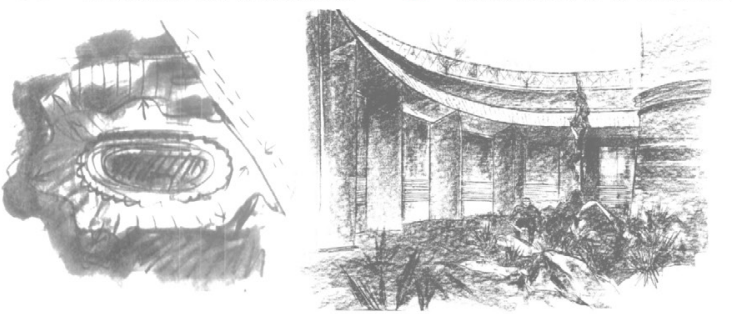

(5) LA IDEA/EL DETALLE

(6) EL ANILLO DRAWING BY V. KRAUSE DRAWING BYV. KRAUSE 


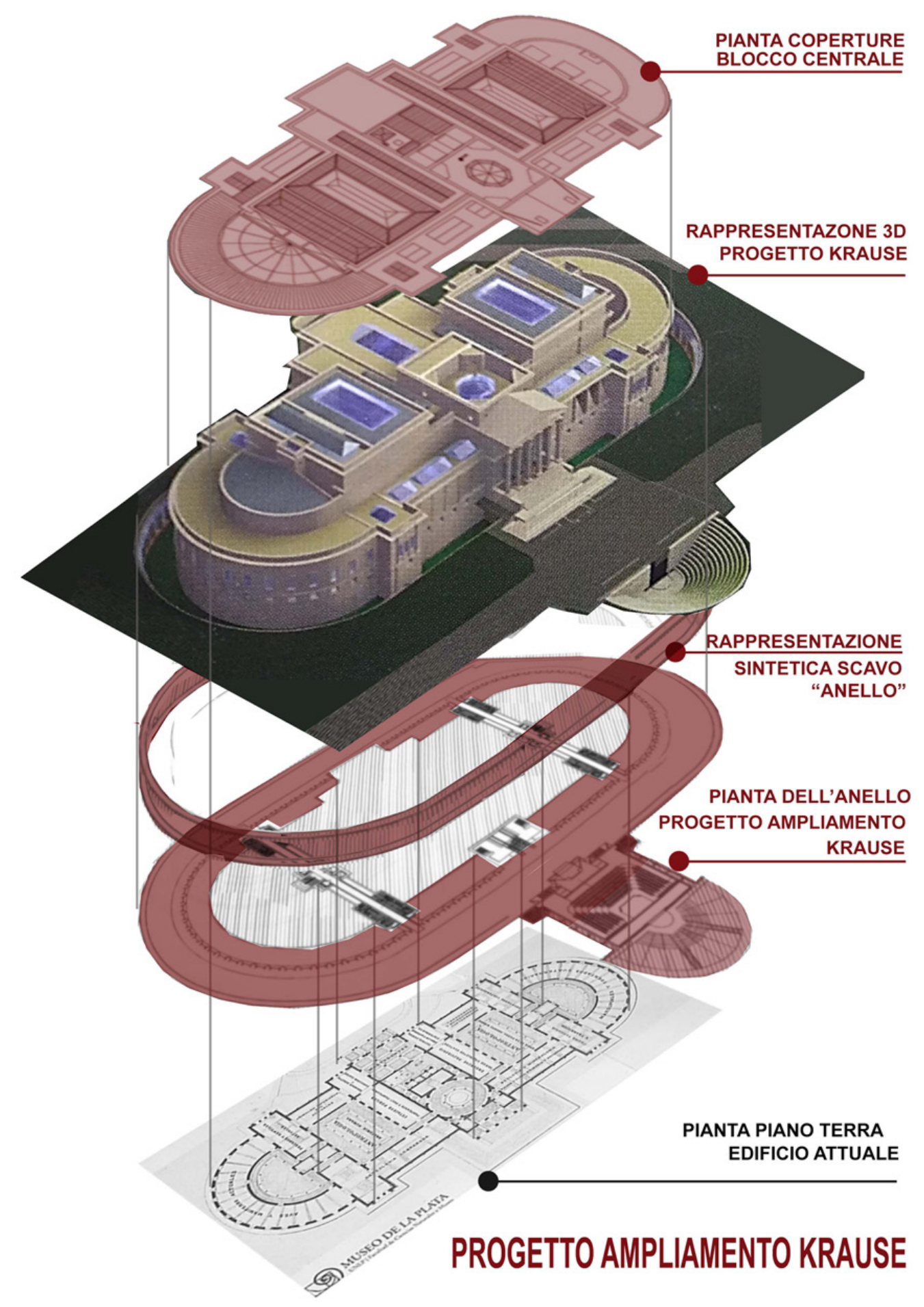


Fig. I0. Formal

planimetric analysis of the enlargement project inserted into the current design, both in plan and section; the proportional ratios between the parts are easily identified.

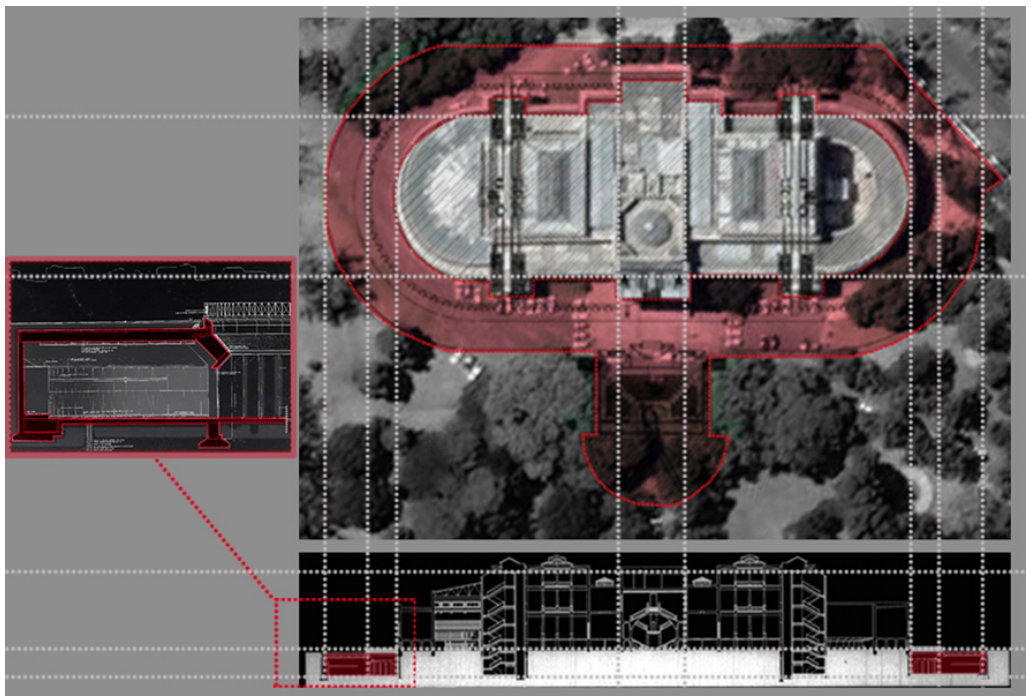

\section{Conclusions}

To preserve the image of a place it is important to gather all graphic archival material, especially if it refers to an important historic, cultural building. In this case the safeguard and linking of historical sources to a real building is even greater because it involves something that has never existed and could be lost. So it is crucial that no trace or evidence of cultural heritage (in this case immaterial heritage) will be forgotten. The study went one step further: it not only compiled the sources, but also systemised and analysed them by creating complex graphic images so that visitors could have a panoramic 'portrait' of an architectural asset and, in particular, of how it could have evolved, but in fact never did.

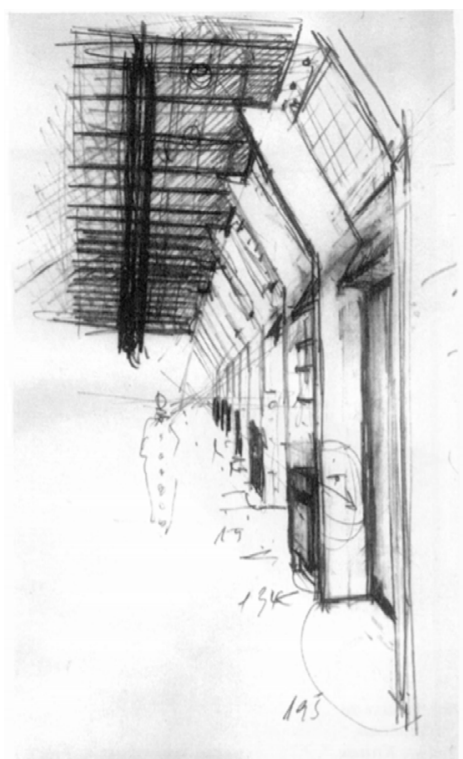

Notes

[I]This contribution was written in close collaboration by all the authors, but more specifically Emanuela Chiavoni focused on the paragraphs Introduction and Conclusions, Maria Belen Trivi on the paragraph Origins of the Museum, Fabiana Carbonari on the paragraph Enlargement Project, Giulia Pettoello on the paragraph Analysis of the drawing and project and, lastly, Francesca Porfiri on the paragraph Study of an excavated architecture. Fabiana Carbonari and Maria Belen Trivi selected the numerous drawings and archival images and also took the photographs of the current interior and exterior of the building. Francesca Porfiri produced Figures I and 10, while Giulia Pettoello produced Figures 8 and 9. 
[2] This topic will be examined by the interactive digital Observatory on the cultural identity of Italo-Argentine heritage currently under development.

[3] This kind of plan was first proposed in Latin America by Professor Albert Gaudry, inspired by the new paleontological galleries of the Museum of Sciences in Paris.

[4] Note that apart from the exhibition areas for the museum pieces and the academic activities that took place after the building was entrusted to the UNLP, the Faculty of Natural Sciences and Museum (founded in 1949) were also incorporated.

[5] Krause maintained that: "Undoubtedly the ambiguous role of the building led to a less expressive structural arrangement of the contents of the interior, but to a more expressive and improved layout insofar as it not only encouraged people to meet, but also led to a more defined "urban character"' [Krause 1997].

\section{References}

Carbonari Fabiana, Chiavoni Emanuela, Porfiri Francesca (2019). Interactive Digital Observatory on the Cultural Identity of Italo-Argentine Heritage. In SCIRES-IT, vol. 9, Issue 2, Caspur-Ciber Publishing, pp. I 05- I I 4.

Chiavoni Emanuela, Porfiri Francesca (2019). Archivi, disegni e cultura, in Salgueiro Walter. La rapresentacion grafica de naturaleza tecnica. In Libro de actas, trabajos extensos, XVI Congreso Nacional de profesores de Expresion Grafica en Ingenieria, Arquitectura Y Carreras Afines, 3-4 ottobre 2019, Olavarria-Pcia. Buenos Aires, Tandil: Universidad Nacional del Centro de la Provincia de Buenos Aires. pp.98-102.

De Carlo Laura (20 I5). Metamorfosi dell'immagine urbana. Rappresentazione, documentazione, interpretazione, comunicazione. Roma: Gangemi editore.

Docci Mario (200 I). Le discipline del Disegno e la ricerca scientifica. In Disegnare, Idee Immagini, 43, pp. 3-6.

Chiavoni Emanuela, Pettoello Giulia, Diacodimitri Alekos (2018). La rappresentazione notturna della città. In Bombassei Elisa, Lucero Hernán, Capellari Fernando (a cura di). Campos, umbrales y poéticas del dibujo. Libro de Actase de Resúmenes: VII Congreso Internacional y XV Congreso Nacional del Profesores de Expresión Gráfica en Ingeníeria, Arquitectura y Carreras Afines. Río Cuarto : UniRío Editora. pp. 300-307.

Carbonari Fabiana, Chiavoni Emanuela (20 I 8). The landscape of the Astronomical Observatory in La Plata, Argentina: form, geometry and colour. In Salerno Rossella (a cura di). Rappresentazione materiale/immateriale. Drawing as (in)tangible representation. Atti del $40^{\circ}$ Convegno internazionale dei Docenti delle Discipline della Rappresentazione. Milano 13-I4-I5 settembre 20 I 8. Roma: Gangemi Editore, pp. I019-1026.

Carbonari Fabiana, Chiavoni Emanuela (2017). II patrimonio culturale della città di La Plata in Argentina: analisi e valorizzazione. In La città creativa. Spazi pubblici e luoghi della quotidianità, Consiglio Nazionale Architetti Pianificatori Paesaggisti e Conservatori (CNAPPC), pp. 655-665

Carbonari Fabiana, Chiavoni Emanuela, Docci Mario et al. (2016). Obras realizadas por los constructores italianos en La Plata entre 1918 y 1945. Arquitectura, análisis y dibujo. In Bertocci Stefano, Bini Marco (a cura di). Le ragioni del Disegno. Pensiero, Forma e Modello nella Gestione della Complessità. Atti del $38^{\circ}$ Convegno internazionale dei Docenti delle Discipline della Rappresentazione, Firenze 15-16-17 settembre 20 |6. Roma: Gangemi Editore, pp. I45- I50.

Gandolfi Fernando, Gentile Eduardo, Carbonari Fabiana (collab.). (2008). GAL Guías de Arquitectura Latinoamericana. La Plata. Buenos Aires: Edi. Clarín.

De Grandis Maria Belén (2019).Vicente Krause. In Anales del IAA, pp. I7I - 190.

Migliari Riccardo (2004). Disegno come Modello. Roma: Edizioni Kappa.

Morlacchi Marcella (2008). Il libro del Disegno. Roma: Gangemi Editore.

Krause Vicente (1997). Tocar lo intocable. La ampliación del Museo de Ciencias Naturales de La Plata. 47 al fondo, 22-29.

Krause Vicente (1998). Ampliación del Museo de Ciencias Naturales de La Plata. In Ambiente, pp. 58-65.

\section{Authors}

Fabiana Carbonari, Universidad Nacional de La Plata, fabianacarbonari@yahoo.com.ar

Emanuela Chiavoni, Sapienza Università di Roma, emanuela.chiavoni@uniromal.itgiulia

Giulia Pettoello, Sapienza Università di Roma, giulia.pettoello@uniromal.it

Francesca Porfiri, Sapienza Università di Roma, francesca.porfiri@uniromal.it

María Belén Trivi, Universidad Nacional de La Plata

To cite this chapter. Carbonari Fabiana, Chiavoni Emanuela, Pettoello Giulia, Porfiri Francesca, Trivi María Belén (2020). In Arena A., Arena M., Brandolino R.G., Colistra D., Ginex G., Mediati D., Nucifora S., Raffa P. (a cura di). Connettere. Un disegno per annodare e tessere. Atti del $42^{\circ}$ Convegno Internazionale dei Docenti delle Discipline della Rappresentazione/Connecting. Drawing for weaving relationships. Proceedings of the 42th International Internazionale dei Docenti delle Discipline della Rappresentazione/Connecting. Drawing for we
Conference of Representation Disciplines Teachers. Milano: FrancoAngeli, pp. I 880-1901. 